\title{
Et »flittigt og oeconomisk« folk
}

Tilvirkning og salg af tekstiler fra Nordøstslesvig i 1700-årene

\section{af Lars N. Henningsen}

Husflid var $\mathrm{i}$ ældre tid en selvfølgelig del af folks tilværelse. På landet var det ofte indtægter fra husflid og andre former for binæringer, som reddede fra fuldstændig ruin i misvækstår. Traditionerne var forskellige fra egn til egn. Nordvestslesvig var præget af en omfattende kniplingsfremstilling, og den er beskrevet tit og ofte. I det nordøstlige Sønderjylland dominerede vævningen. Den har ikke påkaldt sig samme interesse. I denne artikel fortalles om det udbredte væveri $\mathrm{i}$ Nordøstslesvig og om varernes markedsføring $\mathrm{i}$ tiden fra omkring år $1700 \mathrm{og}$ et århundrede frem.

I juni måned 1767 sejlede skipper Michael Clausen ud fra havnen i Aabenraa med sin jagt på $91 / 2$ læster. Kursen var sat mod København, som ofte før og siden. Vareladningen var også typisk, mest landbrugsvarer af forskellig art. De tilhørte skipperen selv eller gode Aabenraakøbmænd. På denne juni-sejlads lastede skibet byg, boghvede, rug, smør, bøgebrænde og knap 4.200 alen hørog blårlarred. Lignende ladninger afskibede Clausen og hans kolleger til hovedstaden mindst 22 gange det år. ${ }^{1}$

Et så stort antal sejladser til Kongens København kunne den agtværdige naboby Haderslev ikke mønstre med sin yderst beskedne søfart. Byens få skibe sejlede mest på Flensborg, men det blev da til et par farter direkte på København hvert år - med det almindelige vareudvalg, landbrugsvarer, larred og uldtoj. I 1753 sejlede Johann Bertelsens lille jagt på 3 læster f.eks. af sted med smør og flyttegods samt uldtøj, hør- og blårlærred, hørdrejl og strømper. ${ }^{2}$

Sådanne forsendelser af hørlærred og uldtøj ses i næsten alle sejladser fra de to sønderjyske byer til København i 1700-årene. Det fører naturligt til en række spørgsmål: Hvor stammer tekstilerne fra? Hvorfra fik man råvarerne? Hvem fremstillede tekstilerne? Hvordan blev de markedsført?

\section{Flittige sønderjyder}

En foreløbig forklaring får vi i de mange rejsebeskrivelser og statistisk-topografiske skildringer fra samtiden. Her blev landsdelen og dens indbyggere gang på gang fremhævet på Kongerigets bekostning. Præsten i Nustrup Johan Arent Dyssel var i sine rejsebreve fra 1763 »Indenlands Reise « ikke i tvivl om, 
at sønderjyderne var langt mere flittige end deres brødre og søstre mod nord og især mod øst. På Als opdagede den opmærksomme pastors blik »igiennem et aabent Vindue en rask Bondepige, der arbeider paa sin Væv, saa det ryster i Huset; uden for er den grønne Plads skiult med Lærred, som bleges i Solen.« Denne flid var endda ikke et særligt alsisk kendemærke, sthi overalt er den Slesvigske Almue overmaade flittig og stræbsom «. Helt anderledes var det på Lolland. Dér var håndarbejde så fremmed for almuen, "at alle smaae ting maae kiøbes fra andre Steder. Hvert et Par Træskoe, som de bruger, kiøber de i Kramboeden, hver Alen Lærret ligesaa". I Slesvig derimod var der tre S'er, som gav velstand: "Sejlads, Spinderok, Synaal ${ }^{3}{ }^{3}$

Dyssels ros af husfliden $\mathrm{i}$ det sønderjyske går igen hos andre samtidige. I 1775 havde pastor Peter Rhode i Utterslev på Lolland, som i sine unge år havde virket i Stepping-Frørup, ikke lovord nok om fruentimmerne i Haderslev amt. De forarbejdede "mange 100 Alen af det fine og grove Vadmel, Hvergarns og stribet Tøy, Hør- og Blaargarns Lerreder« ... "Folket er flittigt og oeconomisk ... man finder, en Bondes Tienestekarle sielden her som i det slaviske Sielland og Laaland, at ligge om Vinteren fra Soel gaaer ned og indtil Sengetiden, række sig paa Bænkene. ... nogle arbeide i Træ, og sælge til Kiøbstæderne, andre giøre Arbeid af Halm, af Svinehaar, af Been etc. andre giøre Koste af Geil, af Lyng, Birk etc. andre reise om og sælge Vahre... Quindefolket er her dets levetid ikke ledigt, kunde de ikke tiene længere, saa væver, strikker, knipler, spinder de, og deslige ${ }^{4}{ }^{4}$

Fremhævelsen af flid og vindskibelighed i Sønderjylland genfinder vi både i Erich Pontoppidan "Den Danske Atlas" (1781) og i August Niemann: "Handbuch der schleswig-holsteinischen Landeskunde» (1799). ${ }^{5}$ En anden kirkens mand, pastor L.M. Wedel fra Everdrup i Sydsjælland, gentog i 1803 i sin »Indenlandske Rejse« den rosende vurdering. Både i Angel og i Haderslev og Aabenraa amter var befolkningens flid en sand kontrast til sjællændernes dovenskab. Fruentimmerne på Haderslev-egnen beflittede sig bl.a. på hjemmegjort tøj af uld og hør. ${ }^{6}$

Lignende toner møder vi også hos senere topografer. ${ }^{7}$ Der synes at være tale om en kliché så fast, at man bliver helt skeptisk. Kan det være rigtigt? Lad os derfor prøve at belyse, hvad der fandtes af husflid, især uld- og lærredsvævning, på landet i 1700-tallet. Synsfeltet vil i det store og hele blive begrænset til det østlige Nordslesvig. Vi vil se på, hvad der blev fremstillet, af hvem og til hvem - var det en produktion til eget forbrug eller til salg? 


\section{Udvalgte tekstiludtryk}

blår det affald som fremkommer ved skætning og hegling af hør og hamp. Efter fornyet hegling kan blår spindes til garn, hvoraf væves blårlærred drejl hør vævet $i$ enkle retlinede mønstre. Finere form for lærredsvævning dynevår kan være fremstillet af olmerdug eller bolster. Olmerdug er halvuldent stof med kæde af hør eller bomuld og islæt af bomuld. Vævedes især $\mathrm{i}$ tværstriber. Olmerdug anvendtes især til overdyner.

Bolster vævedes af hør eller bomuld. Bolstre anvendtes især til underdyner og sommerdyner, og de var oftest stribede på langs.

hvergarnstø| stof med kæde af hørgarn, blår eller bomuld og islæt af uld. Hvergarn anvendtes især til dragtstoffer.

islæt betegner i vævningen de trảde, som går på tværs af tøjet, vinkelret på kædetrådene. Islætten snor sig op og ned mellem de enkelte kædetráde og binder derved tøjet sammen.

kæde betegner i væuningen de tråde, som går i tøjets længderetning. Også benævint trend.

lagen/lacken ældre betegnelse for klæde, dvs. tøj af uld.

lærred fællesbetegnelse for stoffer vævet af hør-, blår eller hampegarn. Islættråden går skiftevis over og under trenden.

tosel eller tussel/tøssel/tressel - er andre betegnelser for hvergarnstøj (s.d.). Udtrykket tosel (tussel, tøssel) er en sammentrækning af sto-søllet“, dvs. vævning "med to søller«. En sølle (sylle) er pá væven de lodrette tráde, som gár mellem skafternes to stokke. Hver sølle har på midten et øje, hvorigennem kædetråden er ført. "To-søllet“ (tosel) er altså vævning med to skafter, "tre-søllet " (tressel) vævning med tre skafter, "fire-søllet" (firsøl) væuning med fire skafter. Skafternes søller ses som de lodrette trăde midt i billedet af væven side 160 .

vadmel hjemmevævet, heluldent stof, især vævet i kipperbinding. Vadmel er ofte et groft og ufarvet stof, som blev meget anvendt af bondebefolkningen.

\section{Udvalgte typer købetøj}

Bielefelder lærred også kaldet Ravensberger lærred, er lærred fabrikeret i grevskabet Ravensberg. Kendt for sin finhed og hvidhed. Det fineste kaldtes ogsá hollandsk lærred.

damask egl. stof fra Damaskus. Stoffet er som regel af hør og vævet i mønstre. flanel eller flonel, er vævet uldent stof. Fries er en form for flonel.

floret uldent glittet stof, især anvendt til kvindetøj, ofte blomstret.

fries uldent, klædeagtigt stof med en hárrig og ládden overflade fremstillet af den dårligste uld.

kalemanke heluldent stof $i$ satinbinding. Det findes både med tværstriber og med blomstermotiver, vævet i damaskteknik. Anvendtes som erstatning for silkedamask; derfor blev ulden stærkt glittet, så overfladen var helt blank.

kammerdug meget fint lærred, det bedste kom fra Flandern.

kattun egl. cotton, bomuldsstof med påtrykte mønstre, kattun-tryk.

netteldug oprindelig tøjer vævet af basttrævler af forskellige arter nælder. Senere betegnelse for fint lærred af bomuld.

serge(s) uldstof.

sirts meget tyndt bomuldstøj med valsetryk. Indførtes fra England i betydelige mængder.

taft glat, lærredsagtig vævet silketøj.

Wahrendorfer-lærred fint bleget lærred, der kun blev vævet i byen Wahrendorf og Frekenhorst af Ravensberger garn. Det kom Bielefelder lærred temmelig nær, men var løsere og lettere. 


\section{Råvarerne}

Får og uld

Den første, og vel vigtigste forudsætning for fremstilling af tekstiler er adgang til råvarerne uld og hør. Ulden fik man overalt fra landets egne får. Men der var forskelle fra egn til egn. Ejdersted var berømt for de utallige får, som gav fin uld. Den blev solgt vidt omkring, til tekstilmanufakturer i Frederiksstad og Ekernførde, og udført til Holland, Hamborg og København. Omkring år 1800 blev landskabets fårebestand anslået til 25.000 stk. I tiåret 1790-1800 løb udførslen af uld op i 386.000 pund. $^{8}$ Også langs resten af vestkysten var fåreholdet stort, og på det magre midtlands heder græssede betydelige fåreflokke. Det gav let adgang til uld i disse egne.

På østkysten så det noget anderledes ud. Her var der sjældent uld i overskud til salg, og hyppigt blev der klaget over, at fåreholdet ikke gav uld nok til hjemmeindustrien. Bønderne holdt altid et vist antal får, for at have den uld der var nødvendig til eget forbrug. Men sygdomme var en tilbagevendende trussel. Gang på gang måtte bestanden genopbygges på ny fra grunden. Sådan hedder det i 1737 fra Haderslev og Tyrstrup herreder. ${ }^{9}$ To år senere berettede magistraten i Haderslev, at der på Haderslev-egnen blev produceret så lidt uld, at der ikke var tilstrækkeligt til byens hattemagere. De måtte i stedet købe andetsteds. ${ }^{10}$

Senere i århundredet gik fåreholdet formentlig tilbage som følge af udskiftningen og opdyrkningen af overdrev, hede- og mosestrækninger. Fårene mentes at skade de mange nye levende hegn, som blev anlagt $\mathrm{i}$ disse år, og fårene blev derfor afskaffet nogle steder. "På Løjt, hvor jorderne havde været udskiftet længe, og hvor man særlig satsede på studeavl, kunne det beskedne fårehold ikke bære en egenproduktion af uldtøj i tilstrækkelig målestok. Uldtøj blev i stedet købt udefra. ${ }^{12}$

\section{Hordyrkning}

Fåreholdet og uldproduktionen havde kort sagt tyngdepunkt på vestkyst og midtland - på østkysten rakte fåreholdet ikke ud over husholdningernes eget forbrug. Omvendt var det med høravlen.

Hørplanten har været kendt i Norden lige siden jernalderen, men den dyrkedes oprindelig mest som næringsplante, af hensyn til de oljeholdige frø. ${ }^{13} \mathrm{Hør}$ til fremstilling af lærred fik man længe gennem import. Flensborg importerede således hør fra Østersøområdet, og byens købmænd solgte det 0 . 1500 videre til bønder i oplandet. ${ }^{14}$ Snart blev der også gjort forsøg på dyrkning, og høravl synes 0.1600 at have været mere udbredt end i tiden efter 1700. I 1592 omtales hørdyrkning i landsbyvedtægten for Agerskov - senere 
gik dyrkningen atter i glemme her og blev først genoptaget fra o. 1807, da handelsspærringen under Napoleonskrigene hindrede importen. ${ }^{15}$ På Hütten ladegård i Gottorp amt dyrkedes ligeledes hør $1613-14 .{ }^{16}$ Det var også her på østkysten, at hørren slog mest fast rod.

I sidste halvdel af 1700-årene blev hørdyrkning særlig udbredt i Angel og Svansen, bl.a. takket være agitation fra den kendte oplysningspræst Philipp Ernst Lüders i Lyksborg. I Hütten amt var høravlen i 1770'erne så omfattende, at der endog blev et overskud til salg uden for amtets grænser. ${ }^{16 a}$

Et fingerpeg om hørdyrkningens udbredelse får man af betegnelsen »hør «'s forekomst som stednavn. "Hørgård « - dvs. en indhegnet hørager - »Hørland«, "Hørløkke« osv. træffes vidt omkring i Nordslesvig. Stednavnet forekommer i nogle af de ældste skatte- og jordebøger (1541 Skrydstrup), i Johannes Mejers kort 1641 (Aabenraa Sønderskov) og hyppigt i slutningen af 1700-årene. "Hør«-navnene er dog ikke jævnt fordelt over landsdelen. I Haderslev østeramt vidner stednavne i samtlige sogne øst for linjen Ødis-Hoptrup om hørdyrkning. På Aabenraa-egnen og i Sundeved og i sognene fra Brøns-Roager-SpandetSkærbæk og østover mod Aabenraa og Løjt træffes hør også hyppigt. I det øvrige Tønder vesteramt og den sydlige del af Aabenraa amt leder man derimod næsten forgæves. ${ }^{17}$

Stednavnenes antydning af hørdyrkningens koncentration i Haderslev østeramt, på Løjt og Sundeved bekræftes af talrige kilder. I hele dette område kendte man til hørdyrkning i 1700-tallet. Men dyrkningen skete normalt kun i det små, ofte i særlig udskilte jordstykker, toft- eller havejord, og til eget forbrug. På den gode jord i Haderslev og Tyrstrup herreder forsøgte mange sig i 1730'erne med lidt hørdyrkning, men det var langt fra nok til at dække forbruget. ${ }^{18}$ I Haderslev vesteramt var hørdyrkning derimod gået næsten af brug 0.1770 . På Gram gods nævnes hørdyrkning f.eks. ikke i 1761, selv om det hørte til fæestebøndernes almindelige pligter at yde såkaldt »hovspind «, dvs. spinde fra ét til otte pund hør eller blår årligt. ${ }^{19}$ I Hviding og Nørre Rangstrup herreder blev der ikke dyrket hør, ${ }^{20}$ og fra Tønder amt klager amtmanden i 1735 over, at det var svært at få gang i hørdyrkningen, da bonden hverken kendte til at dyrke eller behandle hørren. ${ }^{21}$

I Aabenraa amts gode østegn, fra Rise og Kolstrup ved Aabenraa, og fra Nybøl, Stenderup og Sottrup på Sundeved hører vi derimod om hørdyrkning i 1730 'erne, men overalt fremhæves, at omfanget var ringe og udbyttet vekslende. Kun på Løjt havde dyrkningen så stort omfang, at den dannede baggrund for et betydeligt linnedvæveri både til eget forbrug og til salg. På Nørre Jakobsgård i Barsmark kan vi følge hørdyrkningen i detalje takket være gårdmanden Paul Hansens dagbog, som er bevaret for årene 1740-44. Hvert år i foråret kørte bonden til Aabenraa for at købe hørfrø; to eller tre tønder 
blev købt her eller enkelte gange i Flensborg. I maj blev der sået, og høsten faldt $i$ august. En tid senere kunne der sælges af den uforarbejdede hør - men som oftest blev den dog forarbejdet på stedet. ${ }^{22}$

En menneskealder senere, i 1779, gav amtmanden i Aabenraa en mere generel beskrivelse af forholdene $\mathrm{i}$ området: "I Aabenraa amt dyrkes der ganske vist hør overalt, dog bortset fra de fire sogne i Sønder Rangstrup herred Øster Løgum, Bedsted, Hellevad og Hydevad [Egvad], hvor jorden er dels sand, dels hede, som ikke er egnet til at så hørfrø, idet god hør nødvendigvis kræver god jord. Dog er denne dyrkning selv dér, hvor den sker, en biting i landbruget. Følgelig sår jordejeren sjældent mere, end at han kan få nok til egen husholdning«. Kun på Løjt var avlen så stor, at det gav et egentligt overskud til salg: "Indbyggerne i det store og fortræffelige sogn Løjt lagge sig mere end alle andre på høravlingen. Om vinteren sætter den fruentimmernes hænder $\mathrm{i}$ bevægelse. De have og selv vævestole og finde deres regning bedre at sælge det som lærred end at sælge den rå hør «. ${ }^{23}$

Dokumentationen for disse almene udtalelser finder man i nøje udsæds- og høstangivelser for de enkelte sogne i året 1779:

\begin{tabular}{|c|c|c|c|}
\hline & udsæd & høst & \\
\hline Bedsted sogn & - & - & \\
\hline Genner & $34 \frac{1}{4}$ skapper & $38 \frac{1}{4}$ lispund & 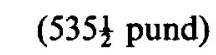 \\
\hline Rise sogn & $62 \frac{1}{2}$ skæpper & $76 \frac{1}{2}$ lispund & (1071 pund) \\
\hline Varnæs birk & 90 skæpper & 75 lispund & (1050 pund) \\
\hline Aabenraa/Kolstrup & 34 skæpper & 27 lispund & (378 pund) \\
\hline Barsø & $38 \frac{1}{2}$ skæpper & 63 lispund & (882 pund) \\
\hline Løjt sogn & 426 skæpper & 823 lispund & (11.522 pund) \\
\hline Sundeved/Nybøl & 949 pund & $32 \frac{1}{2}$ lispund & (455 pund) \\
\hline
\end{tabular}

Tallene viser klart, at det kun var på Løjt, den lokale hørdyrkning muliggjorde et stadigt salg af hørlærred og i mindre omfang af uforarbejdet hør. I alle andre sogne var salgsmulighederne mere tilfældige: "Hvis udsæden velsigner ham [bonden] mere end ventet, så lader han selv væve lærred deraf, bruger det til udstyr til sine døtre, eller giver det til tjenestefolkene, som gemenlig årligt i stedet for pengeløn får nogle alen lærred af deres husbond, så det som sælges ej er af stor betydenhed, dog beror meget derpå, hvorledes høsten falder ud. Et år sælger landmanden mere lærred end andre åringer .... ${ }^{23} \mathrm{Vi}$ kan konkludere, at overskud af hjemmeavlet hør til salg forekom yderst sjældent, og til stadighed formentlig kun på Løjt. De fleste andre steder forudsatte fremstilling af lærred ud over eget forbrug som regel køb af udenlandsk hør hos byernes købmænd.

I begyndelsen af det felgende århundrede blev høravlen udvidet mange 

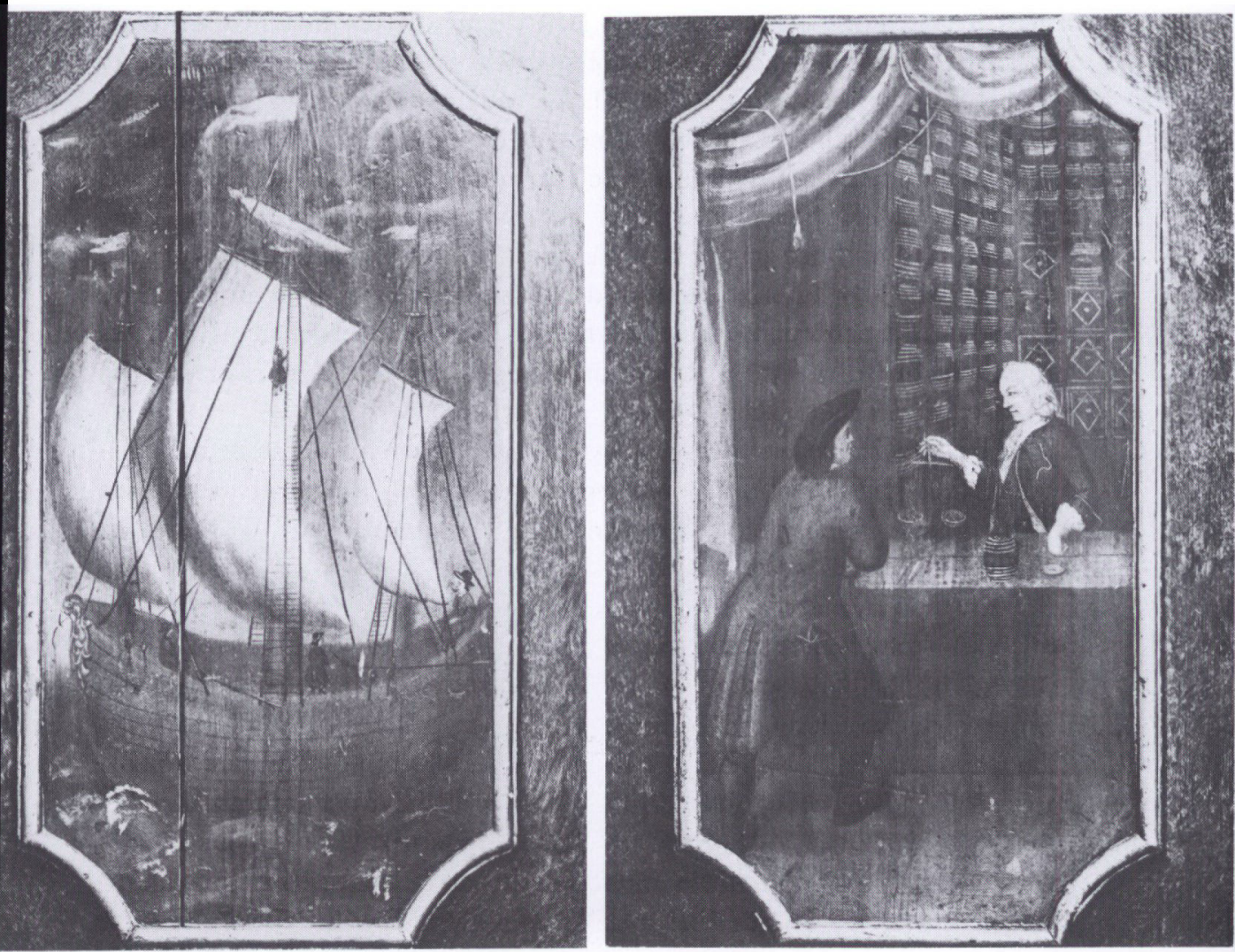

Produktion og forbrug af tekstiler foregik ofte i et samspil med udlandet. En del uforarbejdet her blev importeret ad sovejen fra Østersøområdet, og hos horkrammerne kunne man købe mange slags fremmede tojer. Skibet og butiksscenen her synes at illustrere disse forhold. Motiverne findes pd et linnedskab fra herregården Hesselmed ved Esbjerg. Esbjerg Museum.

steder. I Genner blev der o. 1820 høstet 9-10 skippund eller ca. 182 lispund, (dvs. 2548 pd) hør, i hele Øster Løgum sogn 260 lispund, altså meget mere end i 1779.24 En lignende udvidelse af hørarealet efter år 1800 kendes fra mange andre egne og er udtryk for en almen tendens. Det var den økonomiske krise, som fulgte i forbindelse med Napoleonskrigene og krigen mod England i de første tiår af 1800-årene, som satte gang i hørdyrkningen. ${ }^{25}$

\section{Importeret hor}

Høravlen var kort sagt en usikker branche - udbyttet kunne svigte - og lærred skulle man jo have, hvis man overhovedet havde økonomisk mulighed herfor. Bønderne måtte altså ty til købehør. Der er da heller ikke tvivl om, at 1700- 
årenes husflid nogle steder mere byggede på importeret end hjemmedyrket hør. Det gjaldt også for tiden efter år 1800, f.eks. i Øster Løgum sogn. Herfra beretter pastor Peter Kier o. 1820, at der både i Hovslund og Genner blev drevet omfattende husflid på baggrund af den lokale høravl. Men den slog ikke til, og derfor »kjøbes endog mere Hør til end der avles for om Vinteren at forarbejdes ${ }^{26}{ }^{26}$

Hør var faktisk den tungeste post på importregnskabet. Nationaløkonomen Christian Martfelt (1728-90) anslog den slesvigske import af hør og blår i årene 1763-71 til en værdi af 215.642 rdl., et beløb som kun blev overgået af tømmerkontoen på $231.172 \mathrm{rdl}$, og som lå langt over andre sværvægtere som tobak, jern og stål. ${ }^{27}$

Hørren blev indført til de sønderjyske østkystbyer fra de store hørdyrkningsområder bag Danzig, Königsberg og især Riga. Flensborg var den helt dominerende importby, fulgt af Aabenraa og Haderslev:

Horimport 1763-71 i vardi $i^{27}$

Haderslev

Aabenraa

Sønderborg

Flensborg

Ekernførde

Tønder
$6.580 \mathrm{rdl}$.

$9.764 \mathrm{rdl}$.

1.869 rdl.

$172.488 \mathrm{rdl}$.

$2.215 \mathrm{rdl}$.

1.137 rdl.

Målt i mængde angives følgende importtal for de tre nordslesvigske østkystbyer: ${ }^{28}$

Haderslev 1769: 78 skippund 4 lispund 4 pund hør og blår (21.900 pund) Aabenraa 1739: 121 skippund 1 lispund 15 pund hør $\quad$ (33.909 pund) 1779: 193 skippund hør

1802: 106 skippund hør, $141 \frac{3}{4}$ skippund blår

Sønderborg: 1767: 23 skippund hør/blår

1779: 15 skippund 18 lispund 6 pund hør Anm.: hamp og blårhamp udeladt

(4.458 pund)

Tallene viser tydeligt en indførsel langt større end den hjemlige høst, som er næunt for året 1779.

I alle byerne var hørren - sammen med de øvrige "grove varer jern, salt osv. - en vigtig artikel i købmændenes samhandel med bønderne. Flensborg-købmændenes opland strakte sig over hele Mellemslesvig og store dele af Nordslesvig helt ud til Vesterhavet. ${ }^{29}$ Bønder og småkårsfolk i de ikkehørdyrkende områder var sikre kunder. Ofte kom bønder langvejs fra til storstaden Flensborg, fordi deres varer her kunne sælges mere fordelagtigt 
end i de mindre byer. Hør var da en naturlig del af vognladningerne på vejen hjem.

Hørhandlere fra Flensborg var også faste gæster ved markeder i nabobyerne. De opslog deres boder og solgte den importerede hør til kunder fra by og land..$^{30}$ Endelig optrådte Flensborg-købmændene som grossister i forhold til nabobyernes handlende, som købte hørren hos dem med henblik på videresalg. I toldregnskaberne fra Haderslev og Aabenraa for årene 1710-14 registreres således atter og atter ladninger af hør og hørfrø, som kom med skib eller ad landevejen fra den store handelsby Flensborg. Købmandshuset Valentiner var i disse år den vigtigste leverandør. ${ }^{31}$

Andre leverancer fik Aabenraa- og Haderslev-købmændene ved direkte import. I Aabenraa hjembragte byens skibe hvert år hør fra Riga, Danzig og Königsberg. Hørren var en så vigtig del af købmændenes handel, at denne i 1735 kunne karakteriseres som "hør fra Riga, jern, brædder og tjære fra Sverige, engelsk salt og fransk vin og brændevin samt lidt rug til København og smør, spæk og ost til Stockholm «. ${ }^{32}$ Den livlige direkte handel på Riga og andre Østersøhavne betød, at Aabenraa-købmændene blev ret uafhængige af storebroderen mod syd. Hørren blev solgt videre til byer i Kongeriget, til nabobyerne og til oplandet mod vest helt ud til Vesterhavet. Her indgik hørren i købmændenes bondehandel på linje med tømmer, salt, jern m.v. ${ }^{33}$

I Haderslev var den direkte import mindre. Byens søfart var begrænset. Ganske vist var der både i 1737 og senere i århundredet et eller flere skibe i direkte fart på Riga efter hør. Men ellers var det almindelige, at man fik hør og hørfrø fra Flensborg, evt. fra Lübeck, hvortil byens små jagter gik i regelmæssig fart. På den baggrund specialiserede en enkelt af byens købmænd, Lorentz Musmann sig i handel med hør og tømmer. ${ }^{34}$ Heller ikke omkring 1830 kunne hørdyrkningen på Haderslev-egnen dække de mange lokale væveres behov, så russisk hør fra Riga blev indført til landsognene over Haderslev og Aabenraa. Lave hørpriser gjorde det mere fordelagtigt at indføre end at dyrke hør selv. ${ }^{35}$

I Haderslev blev hør ligesom i Aabenraa og andre byer en vigtig del af købmændenes afsætning til det store og velhavende opland. Hele tiden var købmændene på vagt, når "ubillig« konkurrence syntes at true salget. Gang på gang samlede de sig i protest, når det viste sig, at der var omrejsende hørhandlere på landet, eller når landboerne selv solgte deres produkter uden for amtsbyen og således berøvede byen salget af de vigtige »bondevarer« heriblandt hør. ${ }^{36}$ 


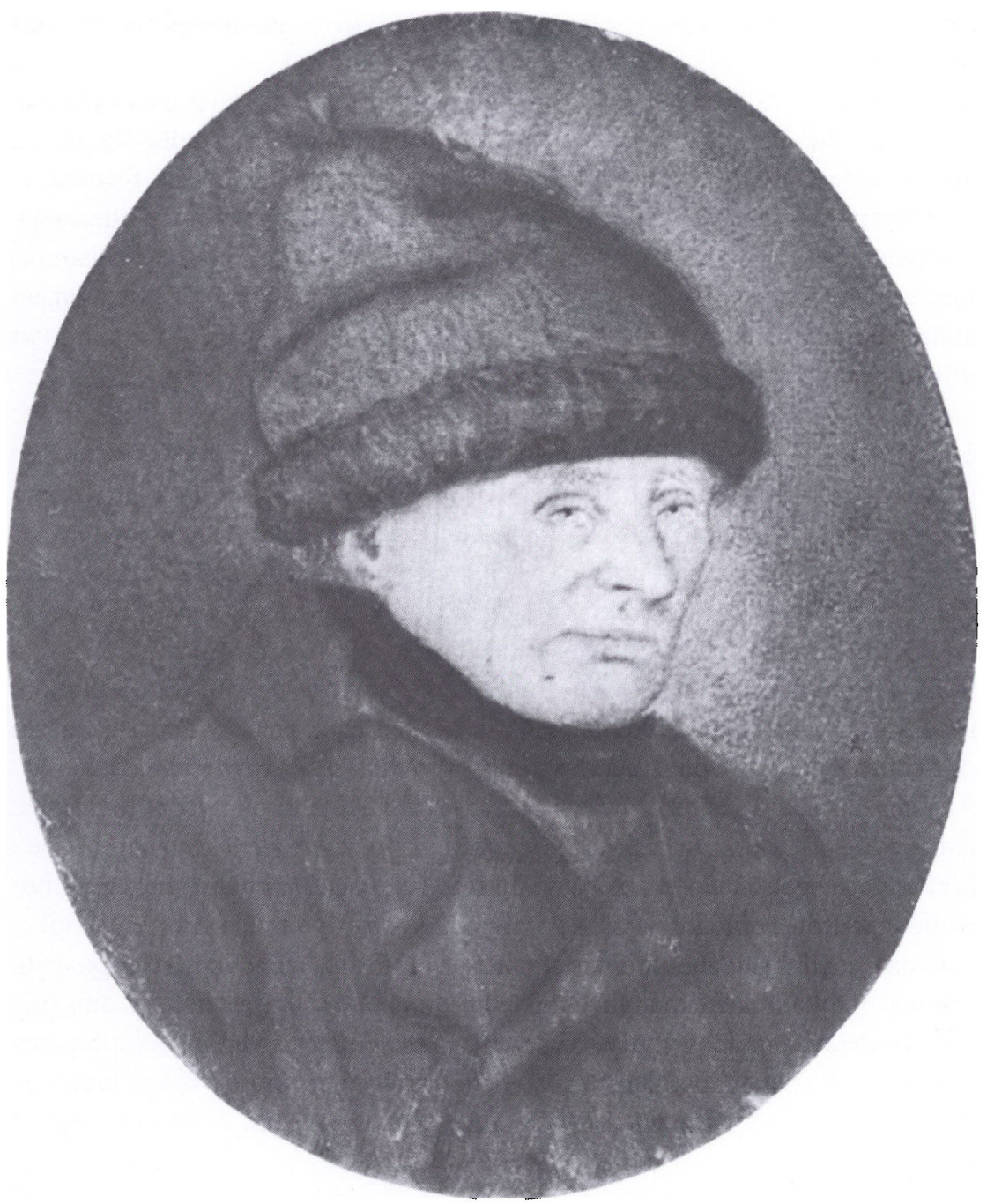

Uldhuer blev $i$ stort tal tilvirket $i$ magre egne og solgt vidt omkring. I Tonder var der fra 1784 en hueog strompefabrik, som havde god afsarning. De varme huer blev solgt helt til Norge, og naturligvis ogsd $i$ hertugdommerne. Pa billedet her har Christian Albrecht Jensen malet den bekendte landmand, mekaniker og matematiker Hans Momsen fra Faretoft i Nordfrisland (1735-1811) ifort en tyk bla uldhue. Gengivet efter Schriften des Kreisarchivs Nordfriesland nr. 5, 1982.

\section{Tekstilvirksomhedens forskellige former}

Strompe- og huestrikning

På landet fandt hør og uld anvendelse $i$ husfliden $i$ snart sagt ethvert hjem. Produktionen var alsidig. 
Den grove uld blev brugt til strømper og andre strikvarer på Rømø, Sild og Før. Hjemmestrikkede strømper fra Femern var ligeledes en stor salgsvare til et bredt marked. ${ }^{37}$ I de magre dele af Nørre Rangstrup herred, især $\mathrm{i}$ den østlige del af Agerskov sogn og i Bevtoft sogn, supplerede strømpe- og huestrikning fra først i 1700-årene de undertiden karrige indtægter fra landbruget - muden dette ville folk for en del næppe kunne leve og betale deres afgifter. ... Men dette uldarbejde indbringer kun lidt, da alt laves af groft spundet uld og altså kun koster lidt. Om vinteren (thi om sommeren står markarbejdet $\mathrm{i}$ vejen) ser man $i$ bondehusene gamle og unge $i$ gang med at kradse uld, spinde og strikke. ... Uldarbejdet bringes til salg $\mathrm{i}$ byerne nær og fjern af folkene selv eller andre landboere, som køber varerne. Dog er denne handel ikke af større betydning«, hedder det i $1737 .{ }^{38}$ Strikkeriet holdt Agerskov-boernes hænder i gang gennem hele det næste århundrede. I 1815 kunne sognepræsten Knud Aagaard berette, at der blev lavet mange grove uldstrømper og trøjer på egnen og især uldhuer, som blev farvet røde og grå og solgt til bl.a. Flensborg og Als eller gennem Haderslevkøbmænd til Kongeriget. Adskillige familier ernærede sig næsten alene af at strikke. Agerskov-strømperne blev solgt helt til marsken og Hamborg og videre. Både gårdfolk og husfolk havde en binæring deraf $i$ ledige timer. ${ }^{39}$

\section{Larreds- og uldvoevning}

Strømpe- og huestrikningen var specialiteter, ligesom kniplingsfremstillingen var det inden for en linje fra Læk ved Tønder over Hellevad til Maugstrup og uden om Øster Lindet, Gram og Fole syd om Ribe ud til Vesterhavet. ${ }^{40}$

Derimod var lærreds- og uldvævningen udbredt overalt. Betydningen af hjemmevævningen fremhæves, hvorhen man end kaster blikket, lige fra Skobøl ved Husum, over Enge i Sydtønder amt til Hütten herred, Angel og Ærø. I de nordfrisiske bondehushold var uldvævningen en ældgammel beskæftigelse. Allerede i 1400- og 1500-årene blev der fra egnene omkring Husum eksporteret betydelige mængder groft hjemmevævet klæde, såkaldt »webbe «/»wobbe« mod vest og øst, og denne væveindustri fortsatte ind i 1600- og 1700-tallet. ${ }^{41}$

Der blev vævet groft uldtøj, især vadmel, og halvuldne tekstiler af blandet hør og uld - dynevår, olmerdug, tussel (også kaldt tosel/tøssel/tressel, dvs. stof med kæde af hør, islæt af uld, det samme som hvergarn). Overalt på landet var det tilladt at væve til husholdningernes eget forbrug og også at sælge den overskudsproduktion, som lejlighedsvis kunne fremkomme. I Haderslev amt var det ifølge en bestemmelse fra 1744 udtrykkeligt tilladt landmanden at forarbejde egne produkter til salg, såvidt håndværkerne ikke led skade derved. Især var det tilladt at forarbejde egen hamp, hør og uld til garn, lærred, strømper og alle slags klædestøj til salg. ${ }^{42}$ 


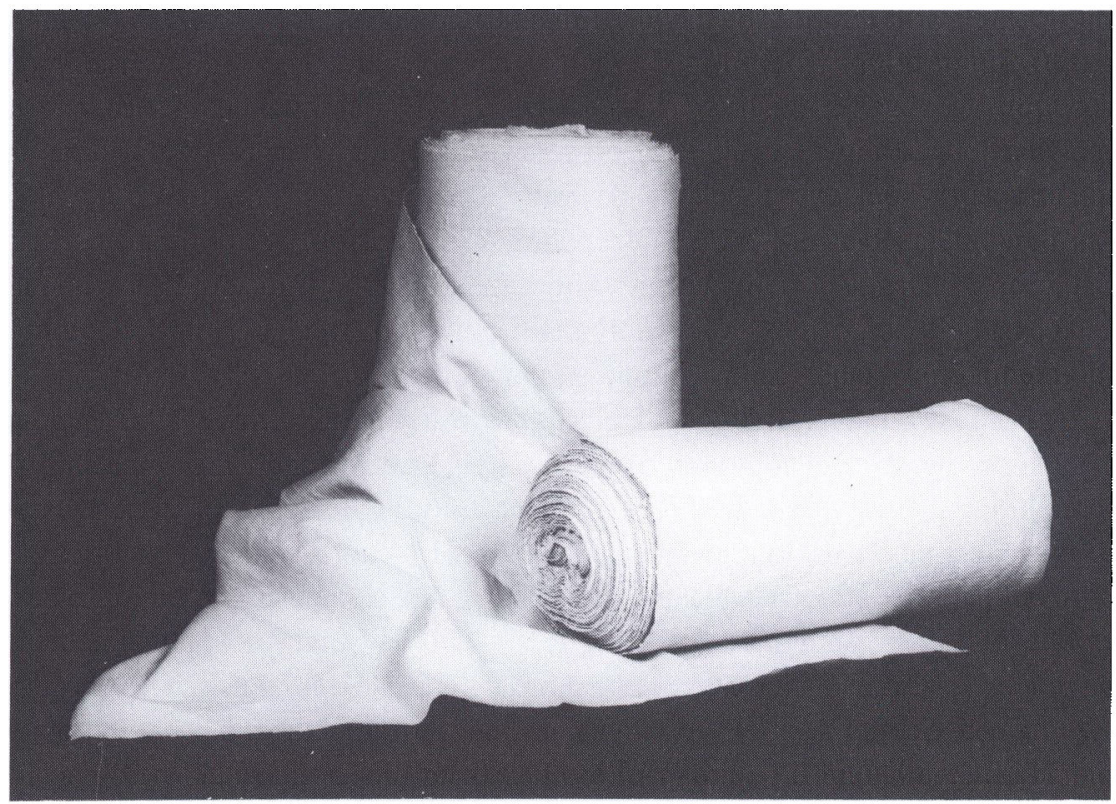

Hørlarredet kom i ganske store stykker fra vaven. Disse to ruller lagenlarred af hør er typiske, begge ca. $70 \mathrm{~cm}$ brede og omkring $30 \mathrm{~m}$ lange. Det var sådanne stykker, som i store mangder blev solgt til Kebenhavn. Rullen til venstre stammer fra Sarup, rullen som ligger ned til højre er fra Kegnas. Foto Museet på Sonderborg Slot.

Hovedparten af disse tøjer gik til husholdningernes egen forsyning, men var der et overskud, blev det solgt. Nogle steder satsede man særligt på at opnå et sådant overskud, som kunne sælges og supplere de øvrige indtægter. Det gjaldt især Nordslesvigs østkyst, fra Haderslev-egnen over Løjt til Sundeved. Lad os nu se nærmere på dette område.

Haderslev amt: I 1774 og i årene derefter skulle amtmændene hvert år indsende oplysninger til Kommercekollegiet om næringsvejenes tilstand. Her finder man korte beskrivelser af husfliden på landet. I Frøs og Kalvslund herred nævnes mangel på hør og uld, og der var kun »lærreds- og uldvævning til eget brug «. ${ }^{43}$ I Hviding og Nørre Rangstrup herred var der ligeledes kun et begrænset lærreds- og uldvæveri, mest til eget brug, med følgende sigende forklaring: "Spinderi er indført, men landmanden driver det ikke til export, kun til eget brug, dels fordi han formentlig ikke finder fordelagtig afsætning i nabobyerne, og dels ikke selv dyrker hør«. Den dyre hør skulle købes, og lærredet gav kun små priser - småfolk fik derfor ikke meget ud af deres arbejde, og den mere velbjærgede landmand foragtede ganske sådan beskæftigelse. ${ }^{44}$

Går vi længere mod øst ændres billedet. Fra Gram herred skriver ridefoged 
Ganderup i 1777: "Hør- og uldspinderiet er mangfoldigt indført som en af landboernes mest passende og nyttigste arbejder, og der fremstilles deraf ikke blot klædningsstykker til eget brug, men de bringes også til salg i byerne«. Dertil kom uldhuer fra Gram, Bevtoft, Neder Jerstal-egnen. ${ }^{45}$ Mest udbredt var væveriet formentlig i Haderslev og Tyrstrup herreder. Her var der næsten overalt, især i små gårde og landbolshuse, væve, hvor kvinderne til eget brug og til salg fremstillede vadmel og stribet uld- og hørtøj. ${ }^{46}$

Aabenraa amt: Vender vi blikket til Aabenraa amt, møder der os de fleste steder det kendte billede: "Mange af amtsundersåtterne, især de såkaldte småfolk, kådnere og inderster, har vævestole og fremstiller lærred og såkaldte hjemmegjorte tøjer samt uldstrømper og handsker. Dog fremstilles der ikke meget mere, end hvad de selv og deres familier kan bruge. Den smule der er til overs sælges i de nærmestliggende byer og flækker «. ${ }^{47}$ Fra Løgumkloster amt kunne amtsforvalter Denis Lucas berette i 1776, at befolkningen havde bragt det temmelig vidt i forfærdigelse af gode uldtøjer og hjemmegjort klæde. ${ }^{48}$

Den konkrete virkelighed kunne være noget forskellig fra sogn til sogn. I den aabenraaske del af Øster Løgum sogn var således 1808-09 90 kvinder i alle de 60 familier beskæftiget med at fremstille uldtøj og linned. Der blev kun arbejdet $\mathrm{i}$ vinterens 20 uger, og resultatet var årlig 1.800 alen uldtøj, 2.0002.400 alen hørlærred, 1.600-2.000 alen blårlærred, 300 par strømper og 200 par handsker. Ulden kom fra egne får, og alt uldtøj gik til eget forbrug. Hør og blår fik man derimod for tre fjerdedeles vedkommende fra udlandet, men der blev kun lidt larred til overs til salg. ${ }^{49}$

Øster Løgum tegner sikkert på mange måder det typiske billede. Afvigelsen finder vi på Løjt. Her var hørdyrkningen rigtig sat i system, og lige fra århundredets begyndelse fremhæves hørvævningen som et særkende for den rige halvø. Her fandt man mere end andetsteds wvæversker, som af den hjemmedyrkede hør fremstiller lærred, som de dels selv bruger, dels sælger til andre.$^{50}$

Fra Varnas, Bovrup, Felsted og Sundeved længere mod syd kom især lagenagtige tøjer af uld, dvs. klæde, og blandede uld- og hørtøjer. ${ }^{51}$

Lad os da prøve at følge de hjemmegjorte tekstilers vej fra vævene - på Løjt og Haderselv-egnen og hvor der ellers blev vævet med salg for øje - og ud til det store marked.

\section{Tekstilernes forarbejdning}

Tekstilerne måtte inden de var endeligt færdige til brug eller salg gennemga mange arbejdsprocesser, forskellige alt efter om der var tale om hørlærred 


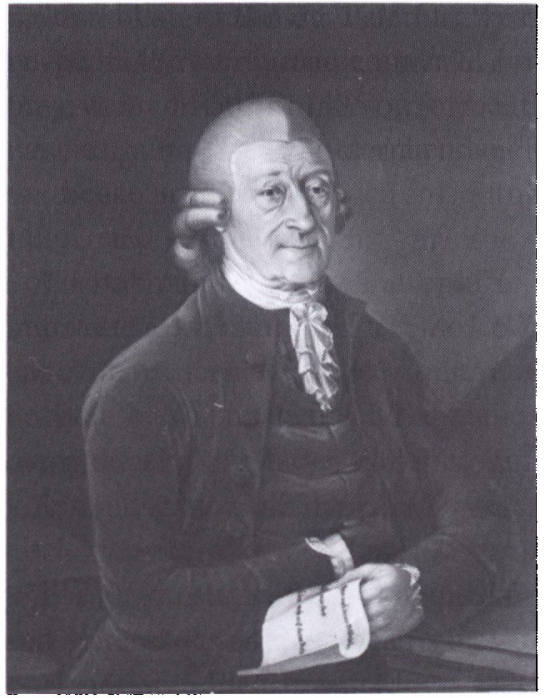

Hos farver Martin Bahnsen (1719-1801) i Aabenraa kunne benderne fra oplandet $f a d$ det hjemmevavede klade valket, presset og farvet. Valkemellen i Sonderskov bearbejdede i sonnen Barthold Bahnsens (1764-1831) tid ärligt 3-5.000 alen klade. Til at varetage farveriet var beskaftiget en farversvend. Martin og Barthold Bahnsen drev også et mindre kattuntrykkeri med salg til bl.a. Jylland og Norge. Martin Bahnsen er her malet $i 1789$ of Jes Jessen. Historiske Samlinger, Aabenraa.

eller forskelligt slags uldtøj. I løbet af vinteren, hvor frost og sne hindrede markarbejdet, blev hørren først heglet, så skættet på skættefoden, og derpå spundet og vævet. Når lærredet kom af væven, kunne det sælges uden videre blegning. "Ubleget lærred « sås hyppigt på markederne, men mere almindeligt var det dog, at de færdige lærreder blev bleget inden salg. Blegningen foregik oftest om foråret. Lærrederne blev lagt ud til blegning på den grønne blegeplads, som fandtes ved alle byer og ved de fleste ejendomme på landet. De frit liggende lærreder kunne nok være en fristelse for svage sjæle. Sager om tyveri træffes hyppigt i kilderne. I 1787 var det f.eks. galt i Stubbæk ved Aabenraa. På blegepladsen ved Lorenz Jürgensens hus lå blårgarn, kniplingstråd, 9 stk. hør- og 9 stk. blår børnelagner, en lille skjorte og to pudevår. Alt blev stjålet, og ejermanden måtte føre proces ved retten i Aabenraa. Storbonden Paul Hansen i Barsmark kom formentlig ud for noget lignende i 1743. For 50 mark lærred fik han stjålet, og amtmanden befalede, at hele Barsmark by skulle gennemsøges for at finde synderen. Det er meget tænkeligt, at det var lærred på blegepladsen, som har fristet en ubefæstet sjæl. ${ }^{52}$

Også uldtøjet gjorde krav på en del arbejdsprocesser, inden det var færdigt til salg. De rå tøjer blev først stampet eller valket og vasket, evt. hos en kornmøller, som havde anlagt en stampe- eller valkemølle. Disse arbejdsprocesser kunne også udføres hos farveren, som farvede garn og desuden sørgede for, at færdigt tøj blev farvet, overskåret og presset. Mange farvede dog selv.

Farveriet var et privilegeret erhverv, og de fleste farvere boede i købstæderne. 
Landboerne måtte altså søge den undertiden lange vej til købstaden, når de ville have uldtøj færdigbehandlet. Det kunne være upraktisk. I Sdr. Stenderup nordligst i Haderslev amt var det sædvane, at folk af egen uld fremstillede tøj til vadmel o.lign. De spandt garnet og vævede det selv eller lod det væve hos andre, men måtte derefter til Haderslev for at få det stampet, skåret, presset og farvet. De bad derfor om, at en dugskærer og farver måtte tillades at bosætte sig i deres egen landsby. Svaret blev dog et afslag i 1741 - i Haderslev amt vedblev der kun at være tilladte farvere i Hjerting, Skærbæk og Toftlund (under Schackenborg). ${ }^{53}$ I Aabenraa amt søgte producenterne sidst $\mathrm{i}$ århundredet til familien Bahnsens farveri og dugvalkevandmølle i Aabenraa Sønderskov (Farversmølle) og senere stampevandmøllen ved Nyknæk ${ }^{54}$ eller til farverne i Felsted, Gråsten og Tinglev. Mest kendt var »æ Farregaard « i Klovtoft, Hellevad sogn. Her havde gårdejer og farver Christian Christensen fra 1778 og frem til sin død i 1799 så stor søgning, at han i 1784 ansøgte om tilladelse til også at holde kro og høkeri - bl.a. af hensyn til dem der langvejs fra søgte farveriet - men det blev dog afslået. ${ }^{55}$

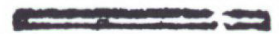

Eatfen Carftenfen auf ber Eleinen DrentDefe im Flenžburger fioro if willeris, eine Bleide dafeloft ans zulegen. - Da Die Lage uno der Boden oiejer Jinfel jur

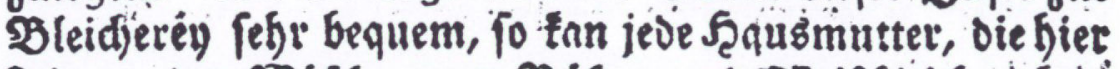

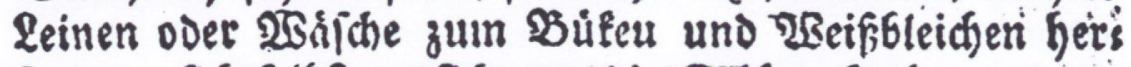

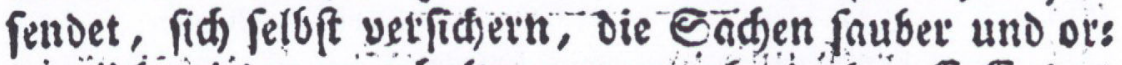

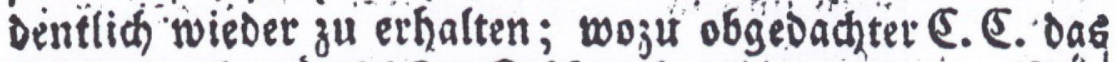

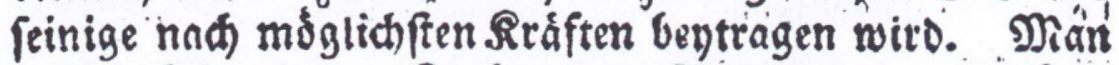

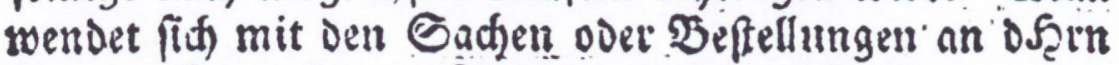

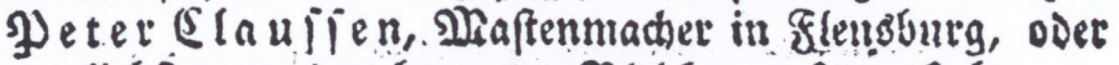
am liebften an Den benanten Sleidjer auf Der Debe.

Blegning blev ikke kun foretaget $i$ tilknytning til vavningen i de enkelte husholdninger. Ved de storre tekstilmanufakturer $i$ ind-og udland var der sarlige blegepladser, og desuden tilbød blegere rundt om at sørge for blegning af tekstilerne fra hjemmevavningen. I drene omkring 1800 finder man $i$ "Flensburgsches Wochenblatı annoncer om blegning. Her tilbyder Carsten Carstensen på Lille Okseo $i$ Flensborg fjord at sorge for blegning af husmodrenes larred eller vasketøj (1801 1/5). 


\section{Markedsføring}

\section{Lokal omsatning eller eksport}

Langt den største del af den omfattende hjemmeproduktion kom som nævnt aldrig på markedet, men blev brugt inden for husholdningerne. Dog blev et eventuelt overskud solgt. Stilles man imidlertid over for spørgsmålet: »Hvor store mængder blev genstand for handel og vandel?«, er det svært at give et præcist svar. Sikre tal for salgets omfang kendes ikke.

En væsentlig del af tekstilerne skiftede ejer på de lokale markeder i Sønderjylland, og nåede ikke ud over hertugdømmets grænser. Denne lokale markedsomsætning var af betydeligt omfang, men at angive mængderne $i$ tal er helt umuligt - kilder findes næppe. Kun i form af eksempler kan vi følge tekstilerne på deres vej fra producent til køber inden for lokalområdet.

En del af tekstilerne nåede imidlertid videre omkring. De blev eksporteret til Danmark nord for Kongeåen, især til København, og evt. til Norge. Når det gælder denne egentlige eksport, er det muligt at angive enkelte tal som viser, hvor store mængder der var tale om. I de få bevarede toldregnskaber findes der tal for udførslen af tekstiler til Kongeriget Danmark og Norge via Haderslev og Aabenraa. Tallene antyder, at der er tale om eksport af væsentligt omfang.

Tekstiludforsel iflg. toldregnskaberne

\begin{tabular}{llcc}
\hline Haderslev & hør/blårlærred & stribet uldtøj & dynevår \\
1767 & 16.040 alen & 4.500 alen & 40 alen \\
1777 & 35.988 alen & 15.145 alen & 1.410 alen \\
1779 & 35.369 alen & 18.018 alen \\
Aabenraa & & uld- og lærredstøj \\
1739 & 13.443 alen & 1.030 alen +1 sæk & 230 alen \\
1743 & min. 13.620 alen & min. 100 alen \\
1769 & 17.579 alen + & & \\
& 1 stk. & & 5 stk. +300 alen
\end{tabular}

Kilde: RA Slesvigske toldregnskaber Haderslev 4-5 og Aabenraa 2-4.

Anm.: Ovenstående tal, som omfatter tekstiler fra både husflid og håndværksvævere, må benyttes med forsigtighed. Alligevel giver de en fornemmelse af, hvor meget der blev afsendt til DanmarkNorge. Drejl er ikke medtaget. Det synes, som om udførslen fra Aabenraa var mest præget af lærred; uld- og hvergarnstøjer sås formentlig mere hyppigt i forsendelserne fra Haderslev.

1 alen: 0,57

Uld- og larredstøj: muligvis hvergarn; kildernes ordvalg er usikkert 
Vil man have mere detaljerede oplysninger, må man gå til andre kilder, især til retsprotokollerne fra de to byer Haderslev og Aabenraa. ${ }^{56} \mathrm{Her}$ findes nemlig kopi af de attester, som for at give toldfrihed blev udstedt angående lokalt producerede varer, når disse skulle sendes til Kongeriget. På dette grundlag kan vi komme lidt nærmere en besvarelse af spørgsmålet om, hvordan de hjemmegjorte tøjer og lærreder blev markedsført. Samtidig får man en omtrentlig angivelse af mængden af eksporterede tekstiler. Desværre kan kildernes benævnelse af de enkelte tekstiler være noget uklar. Opdelingen af stofferne $i$ grupper er derfor i nogen grad udtryk for et skøn. I bilag 1-2 nedenfor side 161-162 er gengivet nogle af de mængdeangivelser, som kan udlæses af retsprotokollerne.

Lad os nu prøve at beskrive $\mathrm{i}$ ord, hvordan tekstilerne nåede fra væven og ud til de forbrugere, som købte dem. Først vil vi se på den mere lokale omsætning på markederne i Sønderjylland, og senere på eksporten.

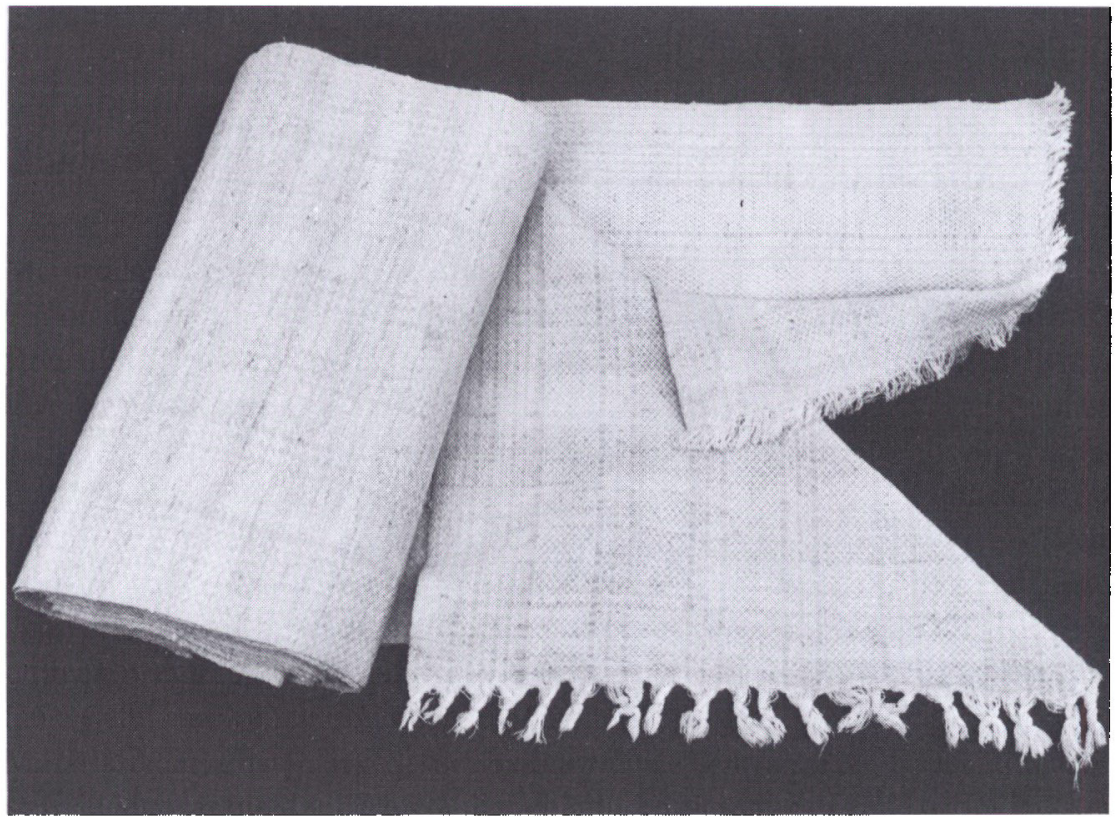

Denne rulle af blarlarred er hjemmevavet $i$ Tombol ved Aabenraa omkring 1870. Materialet er naturfarvet, ubleget blär. Larredet var beregnet til haindklader. Rullen er 12 alen, knap 7 m, lang og $38 \mathrm{~cm}$ bred. Ofte kom larrederne fra vaven i storre stykker end dette. Ruller med en bredde af ca. 75 cm og en langde af omkring 30 meter var almindelige. Jacob Michelsens gård, Kolstrup. Foto Sven Geerthsen, Aabenraa. 


\section{På marked med Aabenraa-tekstiler}

Fra alle egne af amtet kom der tekstiler på marked - omend i forskellig mængde. Fra Øster Løgum beretter sognets præst Peter Kier o. 1820, at husfliden var udbredt. I såvel kirkebyen som i Hovslund og især i Genner blev der fremstillet "Lærred, Tussel og Ulden Tøyer som sælges i Kloster Marked eller andre Steder og indbringer ikke ubetydeligt « ${ }^{57}$

Også fra Løjt solgte man til omegnen i Sønderjylland vestpå. I 1748 blev der klaget over, at folk fra Tønder opkøbte hele partier linned $i$ de to kroer $i$ Løjt Kirkeby - det var ulovligt, for omsætningen burde rettelig ske på markedet i Aabenraa. ${ }^{58}$ Endnu på Løjt-folkemindesamleren Jep H. Riis's tid (18611934) stod mindet om husfliden på Løjt og varernes afsætning i levende erindring: „Paa hver Gaard fandtes een eller flere Vævestole og næsten alle Kvinder forstode sig paa Væveriet. Naar Tøjet var færdigt, gjaldt det om at faa det afsat. Man sørgede saavidt som muligt for at have faste Leveringssteder hos Borgerne i Aabenraa. Vare disse Leveringssteder ikke tilstrækkelige for at faa sin Vare solgt, drog Husmoderen med denne til Flensborg, Løgumkloster, ja undertiden til Tønder for der at søge sin Lykke«. ${ }^{59}$

Det var ikke kun hørlærredet, som blev solgt lokalt. De blandede uld- og lærredstøjer, som blev fremstillet i hele amtet, især til kvindetøj, kom også til salg på markederne. De lagenagtige tøjer af uld fra Varnæs, Bovrup og Felsted blev bragt på marked, når de var stampet, evt. også farvet og overskåret hos farverne i Aabenraa, Tinglev eller Klovtoft. Fra 1792 har vi følgende beskrivelse af forholdene: "De folk som fremstiller det, bringer det selv til marked; dog er fremstillingen til salg almindeligvis ikke særlig stor, fordi de først til sig selv fremstiller alt sengetøj og andre prydelige tøjer, som de bærer«. At afsætningen dog havde nogen betydning fremgik af, at tøjet i folkemunde blev kaldt »Krämerunglük«; det hindrede altså kræmmernes salg af importeret tøj - men indgik omvendt ikke stærkt i købmandshandelen. ${ }^{60}$

\section{På marked med Haderslev-tekstiler}

Haderslev var ligeledes markedsby for overskudsproduktionen af hjemmegjort tøj: "Lærred og det til daglig beklædning nødvendige uldtøj fremstilles også i alle byer til fornødenhed, og i mange væves så meget derudover, at der falbydes og sælges overmåde mange stykker på markederne her, og de føres også uden for amtet«, hedder det i 1774 fra amtshuset i Haderslev. ${ }^{61}$ I 1778 kunne husfoged Emanuel Lassen berette, at landboerne, så snart de havde noget vadmel, tussel eller lærred færdig, bragte det til påske- og Mikkelsmarked i Haderslev. Især lærred blev bragt til salg i anselige mængder og blev købt op og sendt til København. ${ }^{62}$ Men arbejdsvilkårene for væverne i de mange små hjem var ikke de bedste. Ridefoged Johann Friedrich Camerer (1720-1792) i 
Vodder, der fra sin Haderslev-tid havde erfaring med drift af en lærredsfabrik, vidste, at producenterne ofte var under pres. I egne uden tilstrækkelig hørdyrkning skulle de indkøbe hørren dyrt, og de havde ikke kapital til at samle et rimeligt kvantum lærred til salg, men måtte blot for at kunne købe nødvendighedsartikler sælge $\mathrm{i}$ byen, når de havde 20 eller 30 alen færdig. Det gav opkøberne magt, så de kunne byde en latterligt lille pris, og det opmuntrede ikke til at øge produktionen. ${ }^{63}$

Nogle tekstiler blev solgt langt borte. Endnu i 1830 'erne beretter agrarhistorikeren Georg Hanssen, at der blev fremstillet betydelige mængder hjemmeproduceret lærred, vadmel og især tussel, som blev benyttet til kvindetøj og stærkt afsat over Løgumkloster til marsken, til Flensborg, Kiel osv. ${ }^{64}$

Markedernes betydning som omsætningssted for tekstilerne fremgår af mange kilder. I Haderslev blev der først i 1700-årene holdt tre såkaldte årsmarkeder med alskens varer lige fra hør til »Nürnbergkram« og bøger. Der var marked umiddelbart efter påske, ved Jacobsdag den 25. juli og ved Mikkelsdag den 29. september. Her strømmede handelsfolk til, især fra byer sydpå, og landboerne

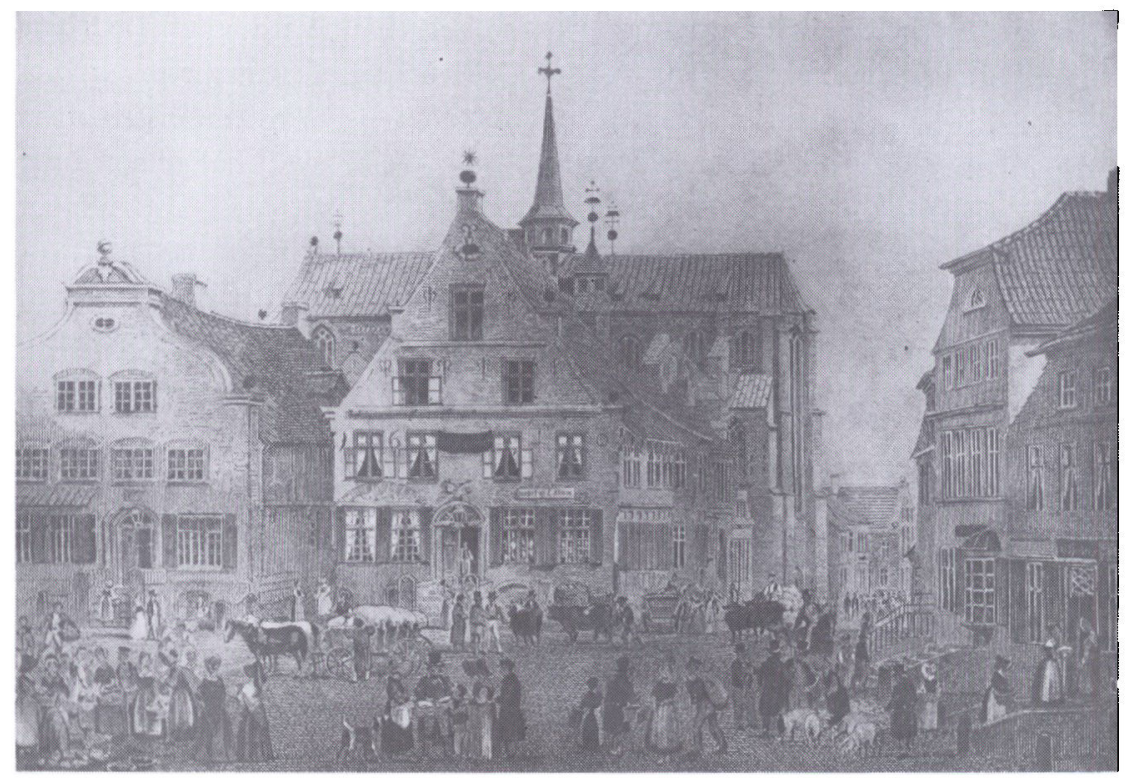

Ved Sondertorv i Haderslev la kobmandsgårdene tat. Her kunne landboerne bytte hjemmevavede tekstiler med købmandsvarer. I købmand Jens Jürgensens bod i huset til venstre (nr. 7) udvekslede bonderne således det hjemmegjorte stribede toj med mjød, brandevin og tobak. Også pd årsmarkederne, som fandt sted pả torvepladsen neden for købmandens vinduer, skiftede masser af tekstiler ejer. W.Heuers stik fra 1847 viser et almindeligt ugemarked. Ved de store pdsse-, sommer og Mikkelsmarkeder var trangslen langt storre. 
mødte frem og fandt købere til deres produkter, og kunne selv få forbrugsvarer med hjem til gengæld.

De mange fremmede handlende var imidlertid alvorlige konkurrenter for byens egne købmænd. Det lykkedes da også i 1718 for købmændene at få årsmarkederne begrænset fra tre til ét - påskemarkedet. Jacobs-markedet skulle nu udelukkende være fiskemarked, og Mikkelsmarkedet være forbeholdt byens egne borgere. ${ }^{65}$ Reformen fremkaldte straks kraftige protester fra forbrugerne, og blandt argumenterne indgik i 1728 hensynet til tekstilproducenterne på landet: De tidligere markeder havde muliggjort, at wundersåtterne fra herværende amt indfandt sig i byen med deres kvæg, korn, honning, gryn, spæk, smør, køer, høns, æg, larred og allehånde hjemmeproducerede tekstilvarer og lignende«, og de kunne på markederne både sælge til fremmede og købe deres kramvarer. For landboerne var det uheldigt, at byens handlende efter markedernes bortfald ikke mere var i stand til at afkøbe dem tekstilerne. ${ }^{66}$

Argumenterne gjorde deres virkning efter nogle år. I $1747 \mathrm{blev}$ de fremmede købmænds besøg atter tilladt ved Mikkelsmarkedet. Landboerne havde herefter igen mulighed for at finde købere på alle de tre årlige markeder.

Haderslev bys købmænd deltog som nævnt i køb og salg af tekstilerne fra landet, og flere af byens købmænd drev manufakturhandel i stor stil. De havde omfattende varelagre af både importerede tekstiler og af hjemlige produkter. De årlige »kræmmerlister« fra 1774 og fremefter nævner, at omsætningen indbefattede »hvad landmanden bringer til salg her af hvidt halvuldent tøj«. Det var lærred og uldtøj af helt anden art end det importerede tyske og langt mere solidt ... «tøjerne, som fremstilles her i landet, har fortrinnet frem for det udenlandske såvel i pris som kvalitet og anskaffes derfor fortrinsvis til handelen her og afsættes igen«. Fra 1780'erne omfattede købmandshandelen desuden wuldhuer, som bondepiger $\mathrm{i}$ nogen tid har fremstillet på landet og som i særlig grad finder afsætning her «. ${ }^{67}$

De jævne tekstiler fra landet var altså salgbare til det almindelige publikum og indgik i omsætningen i mangen købmandsgård. Det var f.eks. tilfældet $\mathrm{i}$ rådmand og kirkeforstander Jens Jürgensens (ca. 1730-1793) store forretning på Torvet. Ejendommen ligger der endnu (nr. 7) næsten uændret efter den ombygning, som den nyetablerede købmand lod foretage o. 1760. Det var en rigtig blandet storhandel med korn, mjødbryggeri, brændevinsbrænding, tobaksspinderi og dertil handel med jævne lærreds- og uldtøjer og de på landet fremstillede stribede tøjer. ${ }^{68}$ Det var ikke svært for sælgerne fra landet at finde frem til købmandens bod - markedet fandt jo sted lige uden for hans vinduer, og det er ved disse lejligheder, Jürgensen fik sit lager suppleret op.

Næsten samme gode position over for landboerne havde Jürgensens lidt aldre kollega på den anden side af Torvet, rådmand og købmand Peter Raben 
(1717-1774) i ejendommen Klosteret 1 på hjørnet af Lavgade ud mod Torvet. Peter Raben startede som købmand i 1744 og opbyggede en alsidig handel med omegnens bønder. Da han døde $\mathrm{i} 1774$, blev varelagrene registreret $\mathrm{i}$ mindste detalje. Der var hør, mængder af tømmer, jern, søm og en broget mangfoldighed af tekstiler, dels importerede tøjer (f.eks. fransk, schlesisk, Wahrendorfer- og Bielefelder lærred), dels blå- og hvidstribet lærred, uldne mands- og kvindehuer, strikkede og vævede uldstrømper; sidstnævnte kan meget vel være købt af folk fra landet, f.eks. når de kom til marked i byen. Rabens forbindelser ses bl.a. af de ca. 600 gældsposter, som bønderne i oplandet var noteret for i hans bøger. ${ }^{69}$

Raben deltog altså i handelen med lokale tekstiler. I 1747-48 sendte han og broderen Hans Raben kniplinger og andre tekstiler til Norge. Ved flere lejligheder bekræftede Peter Raben, at fremmede, som var kommet til marked, i hans hus havde købt lærred og uldtøj af landboere. Heraf kan vel sluttes, at landboere ofte ved markedstide mødte op i byens købmandsgårde og her fandt afsætning for resultaterne af vinterens hjemmeflid. Købmændene købte dels ind til eget lager og videresalg, dels synes de også at formidle bøndernes salg til andre. ${ }^{70}$
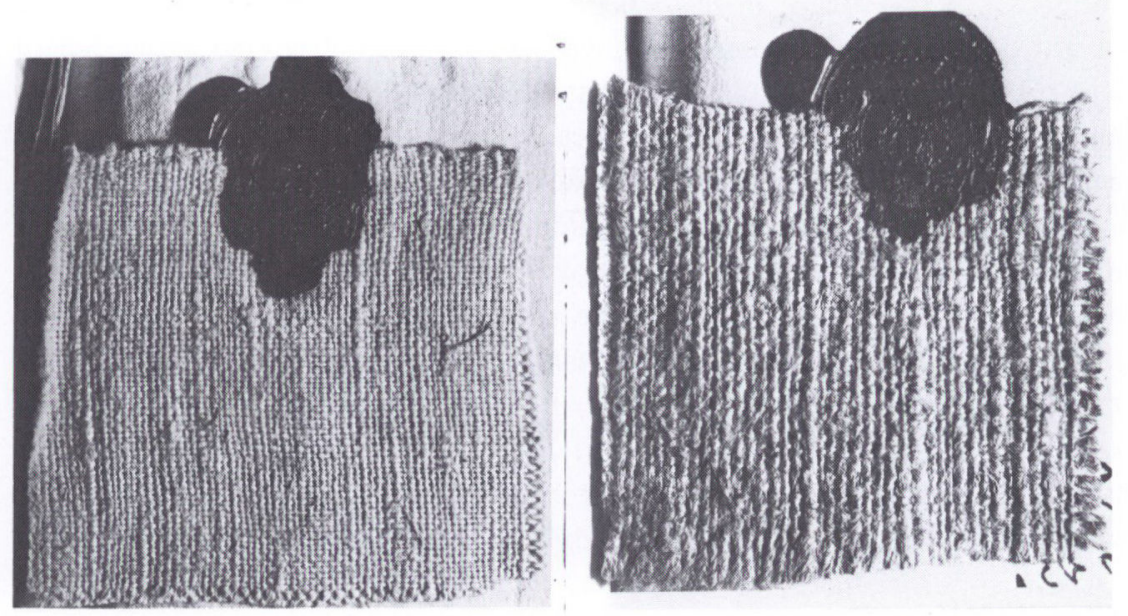

Centraladministrationen $i$ Kobenhavn var bekendt med, at "der ikke blot $i$ det Slesvigske, men også $i$ Jylland og andre provinser her i Danmark årligt forfardiges en stor mangde larred", og man onskede regimenterne munderet i den slags indenlandske tekstiler. Prover pd de onskede tøjkvaliteter blev udsendt til mulige leverandorer. I 1765 lovede Jep Jessen Krag i Aabenraa at levere 2.000 alen hvidt larred som proven til venstre og 2.000 alen blarlarred som proven til hajre, begge typer i en bredde af ca. $78 \mathrm{~cm}$, og til en pris af 5-6\% skilling pr. alen. Det må antages, at leverandoren fik tekstilerne fra vavere $i$ og uden for Aabenraa by. LA Ab Ab amt C II' nr. 168. Fot Th. Lawaetz, Aabenraa. 
Eksport

Via markederne og byernes købmandsboder nåede tekstilerne ud til købere i by og på land inden for Sønderjyllands grænser. En del nåede meget længere bort. $^{71}$

På Aabenraa-egnen var det især hørlærred, som blev eksporteret, og det meste gik til København. Det er denne eksport, som ses af tabellen side 162. Lærredet kom særlig fra Løjt sogn. Her var der på alle gårde en eller flere vævestole, og der blev vævet til salg af de mange småkårsfolk: »Disse bringer det bleget på marked i Aabenraa og Løgumkloster. Hovedparten af det går fra Aabenraa til København«, hedder det i en beretning fra 1792. ${ }^{72}$

Også bondekonerne spandt og vavede, og når det gælder den før nævnte Paul Hansens gård i Barsmark, er vi så heldige at kunne følge tekstilerne så at sige lige fra væven og ud til forbrugeren i København. Gang på gang satte bonden og hans kone Mette Bossen sig til vogns for at køre til Aabenraa. Med sig havde de produkter fra landbruget, enkelte gange uforarbejdet hør til købere i byen eller til farveren. Andre gange var det salgbart hørlærred. I 1742-44 var køberen flere gange en Andreas Asmussen. Han aftog en del. Den 31. marts 1744 betalte han $11 \frac{1}{2}$ rdl. for lærred. Med den almindelige alenpris på 5 skl svarer dette til en leverance på ca. 220 alen eller ca. 125 m lærred. I 1743 fik Paul Hansen betaling for lærred fra en anden Aabenraa-køber, nemlig Jes Jepsen Krag. Begge disse to herrer genfinder vi med ret stor sikkerhed blandt de Aabenraa-borgere, som levede af at opkøbe og udskibe lærred til København. Kredsen er altså sluttet: hørfrøet fra Aabenraa-købmændene blev efter høsten hos Paul Hansen forarbejdet til lærred, som via Aabenraahandlende nåede til København - og honoraret endte i bondens lomme. ${ }^{73}$

I Aabenraa var flere af byens solide købmænd, som i øvrigt handlede med landbrugsvarer, specialiseret $i$ opkøb og videresalg af de hjemmegjorte tekstiler, og de kunne afsætte ganske store mængder. Det var i 1700-årene folk fra købmandsoverklassen som Niels Jürgensen (ca. 1682-1777), rådmand Diderich Diderichsen, Jacob Schwennesen (1700-1783) og rådmand Simon Jensen (1729-1805). ${ }^{74}$ De sendte tøjet til København som en del af blandede ladninger af landbrugsvarer - havre, byg, malt, boghvede, rug, smør, ost, huder, mjød osv. Alt gik afsted med skib, og den enkelte købmand kunne på årsbasis godt afskibe ca. 10.000 alen tekstiler. Det var bleget eller ubleget hørog blårlærred, blå- og hvidstribet lærred, stribet uld- og hørtøj og mindre partier oftest stribet uldtøj. De ofte store sendinger var hyppigt pakket i sække sammensat af hundredvis af enkeltstykker lærred eller uldtøj på 40-60 alens længde (ca. 22-34 meter).

En del skippere - og vel især skipperkonerne - deltog i tekstilhandelen, ligesom deres kolleger på Bornholm, ${ }^{75}$ og denne handel var sikkert ofte ligeså 
vigtig for dem som det at føre skib. En af de aktive skipper/købmænd var Jep Jessen Krag. Da der i 1765 indløb en forespørgsel fra militæret om levering af indenlandsk lærred til regimenternes mundering, tilbød han at levere 4.000 alen $(2292 \mathrm{~m})$ i 5 kvarters $(=\mathrm{ca} .78 \mathrm{~cm})$ bredde. $^{76}$

Også matroser fra Løjt tog hyppigt et eller flere stykker stof med i skibskisten $i$ håb om at tjene en skilling ved salg $\mathrm{i}$ storstaden København. Endelig kom der folk langvejs fra til marked i Aabenraa for at opkøbe tekstiler. I 1752 møder vi f.eks. en Carsten Petersen Due fra Odense - han købte 23 stk. hør- og blårlærred og to stk. tussel for at tage det med til Odense. ${ }^{77}$ Det hændte også, at den enkelte væverske selv afsendte nogle af sine produkter til København eller en anden fjern destination. De tilrejsende småhandlende og de lokale producenter tegnede sig dog personligt kun for en lille del af eksporten. Normalt var det Aabenraa bys købmænd og enkelte skippere, som dominerede videresalget til København af de store mængder hør- og blårlærred fra Løjtland og af de mindre partier blandede stoffer og uldtøj fra et bredere opland.

I Haderslev blev der på samme måde afsat tekstiler til kongeriget både via markederne og gennem købmandshandelen. ${ }^{78}$

Nogle købere til landboernes tekstiler kom langvejs fra. Hvert år ved påskeeller Jacobs-marked træffer vi f.eks. et par opkøbere fra Odense. Den ene var Carsten Petersen Due, som vi kender fra Aabenraa. Den anden var skomager Johannes Wiese og hans kone Johanna. En eller flere gange årligt mødte de op ved markederne og købte stribet uldtøj eller lærred af byens borgere og af landboerne, eller de opsøgte producenterne på landet. I 1753 hentede Johanna Wiese to stykker stribet uldtøj i Råde. Når de havde handlet, drog de afsted til Odense med færre eller flere, helt op til 50 stykker uldtøj eller lærred i oppakningen.

En del af omsætningen lå hos småhandlende i Haderslev, som havde specialiseret sig $\mathrm{i}$ opkøb og videresalg af de hjemmegjorte tøjer. Mange af disse handlende var kvinder. Cathrine von Nessen (1700-1762) på Papegøjen i Gammel Haderslev sled energisk $i$ denne branche. Hun var ustandselig på farten både før og efter ægtemanden, feltskær Christopher von Nessens død i 1751. På landet købte hun kniplinger, uldne strømper, dynevår, lommetørklæder, hør- og blårlærred og uldtøj, og med disse bylter gik rejsen år efter år østover, til markeder $\mathrm{i}$ Odense og på Sjælland og især til København. Det hændte, at manden hjemmefra afsendte flere varer til konen, mens hun var på salgsrejse $\mathrm{i}$ København. Nogle gange var det datteren og tjenestepigen, som rejste af sted, eller varerne blev blot sendt med post til køberne i Kongeriget. Fru von Nessens forretning var ganske omfattende. I 1746 er noteret 
1.170 stk. kniplinger, 10 stk. og 200 alen lærred, 39 stk. hjemmegjort tøj og 40 alen dynevår. I 1752 omtales 353 stk. kniplinger, 26 stk. lærred, 4 stk. uldtøj, 29 par strømper og 1 overseng med puder. Endelig i 1757 var der 357 stk. kniplinger, 200 stk. og 2132 alen lærred, 159 alen uldtøj, 20 alen dynevår og 23 par strømper.

Catharina von Nessen var nok den flittigste af de omrejsende handlende. Men der var mange andre, og det er bemærkelsesværdigt, at denne handel for en stor del lå i kvindernes hænder. De optrådte selvstændigt, og rejste vidt omkring for at afsætte husflidsvarerne. Sortimentet var stort, ikke blot kniplinger, strømper, lærred og uldtøj, men også dusinvis af kunstige blomster (gemachte Bluhmen). De blev især fremstillet i Haderslev by, nogle få på landet, og blev brugt til udsmykning af tidens kvindedragt - til bryst- og hovedbuketter eller til halsgarniture. ${ }^{79}$

De omrejsende handlende tegnede sig dog ikke for hele eksporten. Ligesom i Aabenraa blev en del af tekstilerne afsendt pr. skib. Allerede i 1704 nævnes flere skippere, som tog lokalt produceret hør og blårlærred med til København ${ }^{80}$ og denne trafik fortsatte århundredet ud. I 1733 var skipper Jørgen Hundevad fra Haderslev gentagne gange i København med i alt langt over 10.000 alen hør- og blårlærred samt dynevår, tussel og uldtøj. ${ }^{81}$ I 1777 sejlede et par skippere til Assens og Middelfart med bl.a. uldtussel, hør- og blårlærred, men de kom tilbage med det usolgte. Skipper Hans Boyskov var flere gange i København med hør- og blårlærred, dynevår, blå- og hvidstribet lærred, drejl og stribet uldtøj. ${ }^{82}$ Nogle af disse ladninger kom nok fra de professionelle vævere i Haderslev, andet har været hjemmegjorte tøjer, måske opkøbt og videresendt af byens købmænd. Disse skibsladninger hører med til det samlede billede af omsætningen af hjemmegjorte tøjer - ligesom de mængder, der blev forhandlet fra købmændenes hylder eller blev bragt videre af omrejsende handlende.

\section{Forlagsindustri?}

Det er flere gange næunt, at købmændene indtog en vigtig plads i formidlingen af tekstilerne fra de mange spredte vævere og ud til markederne i det fjerne, især i København. Men hvordan var forholdet mellem købmænd og producenter? Var væverskerne afhængige af købmændene på den måde, at disse finansierede arbejdet, leverede råmaterialerne, og aftog varerne til videre forhandling? Et sådant system, hvor købmanden ejede varerne lige fra det rå produkt til den færdige vare, kaldes "forlagsindustri«, omend den var organiseret på husindustriel basis. Man kan også tale om »forlagt husflid«. Den sønderjyske 


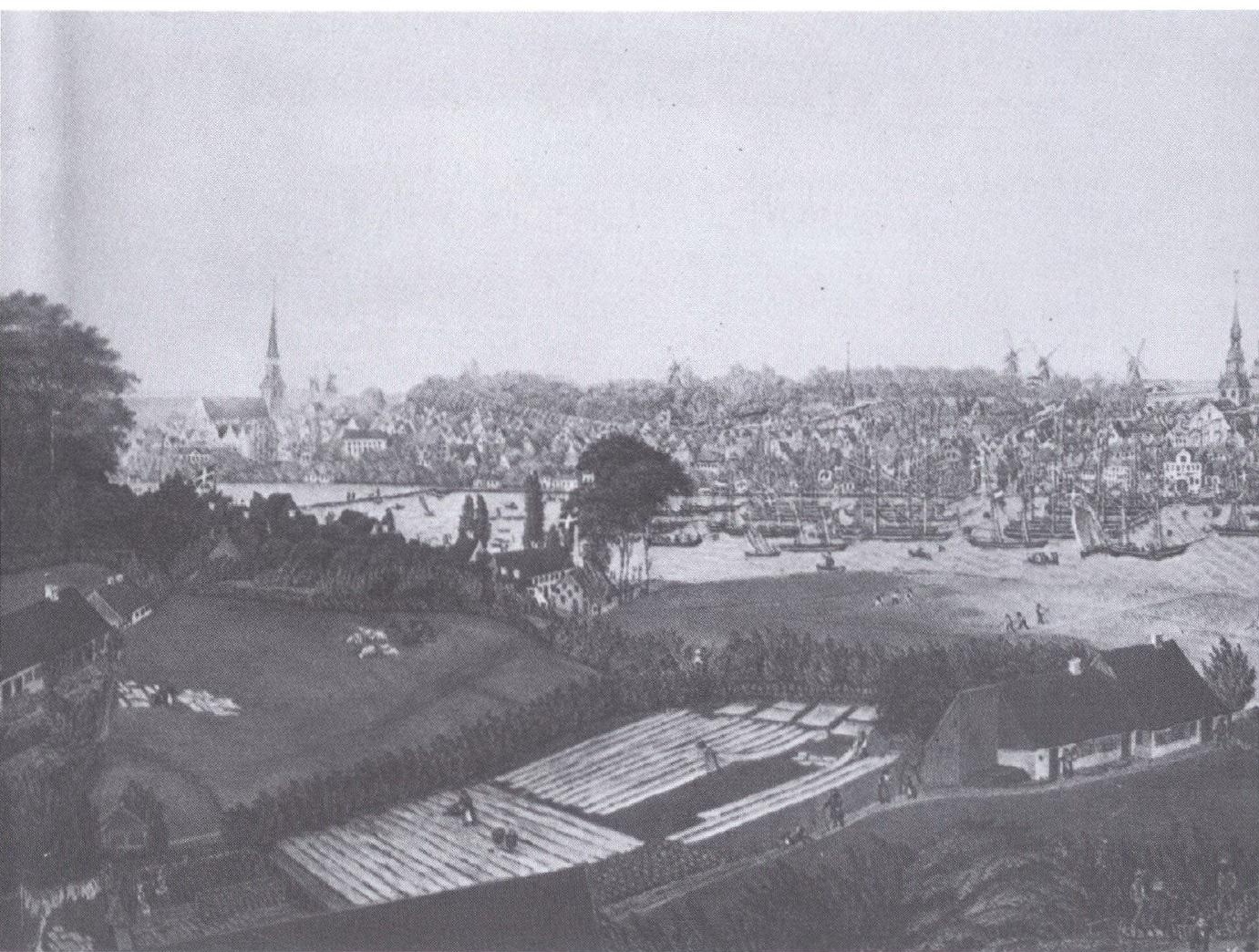

Det var ikke kun på landet, der blev spundet og vavet. I alle kabstader var der vaveri som husfid og desuden en del erhvervsvavere - f.eks. larreds- og drejlsvavere. Produktionen blev solgt lokalt, pd markeder i Danmark eller til København. I Flensborg stod der ofte købmandskapital bag tekstilfremstillingen, og en del blev eksporteret til Norge. Den omfattende produktion skabte behov for store blegepladser - og sådanne bredte sig derfor uden for alle byer. De ses på gamle stik. I Flensborg var der $i 1775$ "4 store blegepladser, som om sommeren alle ligger fulde af lorred, hvilket bevidner de gode husmodres fidณ. Blegepladserne ses tydeligt på dette udsnit af T. B. Wilms litografi 1844, her gengivet efter bindet pd Flensburg 700 Jahre Stadt - eine Festschrift. 1984. Bd. I.

kniplingstilvirkning på vestkysten er et godt eksempel. ${ }^{83}$ Eller var producenterne selvfinansierende og selvstændige, så de helt selv styrede fremstillingen og blot drog til bys og afsatte varerne til købmanden mod betaling, når der var noget færdigt?

Et klart svar på spørgsmålet: »forlagssystem eller ikke?« kan næppe gives. På den ene side har der tilsyneladende ikke rådet et afhængighedsforhold mellem købmænd og producenter i lighed med, hvad der kendes i kniplingsbranchen. Bøndernes lejlighedsvise salg af uldtøj og tussel på basis af hjemlige 
råmaterialer foregik sikkert helt på producenternes egne betingelser. ${ }^{84} \mathrm{På} \mathrm{den}$ anden side er det sandsynligt, at fattige landvæversker og småkårsfolk, som måtte købe hørren i byerne, ofte har stået $\mathrm{i}$ et vist afhængighedsforhold til købmanden. Et indlæg i tidsskriftet Schleswig-Holsteinische Provinzialberichte i 1790 trækker klart linjerne op: Hørdyrkningen var helt utilstrækkelig. I stedet overlod høkeren landmanden det nødvendige hør på kredit windtil denne [landmanden] atter bringer ham lærred, så meget eller så lidt som han kan fremstille af den modtagne vare. ... Bringer han nu sit lærred til købmanden, som har ydet ham kredit, så byder denne ham vel 3 eller højst $3 \frac{1}{2}$ sk. pr. alen $\%$. En højere pris ville have animeret til en langt større produktion. ${ }^{84 a}$

Citatet antyder en klar afhængighed mellem producent og købmand. På denne måde kan Aabenraa-købmændene godt have indtaget en aktiv plads i en del af lærredsvævningen på Løjt. Ganske vist var en del af hørren hjemmedyrket og ikke leveret fra Aabenraa. Men mon ikke der også indgik importeret hør $\mathrm{i}$ arbejdet? I alt fald kan nogle af de fattige indsiddere blandt væverne godt have stået $i$ et fast forhold til en købmand, som sikrede afsætningen af deres arbejder, og som altså gav dem et sikkerhedsnet. De store mængder lærred som gik til København kan være eksempel på forlagssystemet i et begynderstadium. Ganske få antydninger $i$ kilderne peger i retning af et sådant afhængighedsforhold mellem købmand og producent. I 1772 skulle rådmand og købmand Peter Bennick Hansen i Aabenraa (1723-1809) således berette om, hvad han havde afsat af indenlandske "fabriksvarer «. Svaret er bemærkelsesværdigt: "Jeg melder, at jeg rigtignok i afvigte år har forlangt og afsat en mængde her $\mathrm{i}$ landet forfærdigede varer. Men at fremlægge attest derpå fra fabrikørerne er mig så meget mere umuligt, som de næsten alle er fattige og mine debitorer, som hver gang, når de leverer varer, holder afregning med mig, og hverken de eller jeg noterer det leverede eller modtagne. $\aleph^{85}$ Peter Bennick Hansen hørte ikke til de typiske lærredshandlere, men udtalelsen viser, at han indtog en kreditorrolle over for mange af leverandørerne - og noget lignende kan meget vel have været tilfældet, når det gjaldt forholdet mellem de fattige vævere på Løjt og de store Aabenraa-købmænd Niels Jürgensen, Jacob Schwennesen, Simon Jensen og deres mindre kolleger.

I handelscentret Flensborg møder vi tilsvarende forhold, og der kendes eksempler på egentlig forlagsproduktion. Flere af byens købmænd lod selv forskellige typer tekstiler fremstille i byen og på landet til videre forhandling. F.eks. lod købmand Hans Cordt Göttig en del varer fremstille for egen regning. En sådan købmandsstyret produktion var dog nok undtagelsen. For de fleste vævere på landet har en mere eller mindre udpræget selvstændighed formentlig snarere været det karakteristiske. Billedet var broget. Det mest almindelige var, at bønderne kom personligt til stads med deres produkter - lærred, uldtøj, 
dynevår, sejldug, drejl. De gik fra dør til dør og falbød varerne, og hos tekstilkøbmænd som Martin Feddersen, Hans Cordt Göttig, Johann Braak og Asmus Boht fandt de faste kunder. Salgerne var »beskedne folk, som ikke kunne skrive«, og købmændene kunne derfor ikke dokumentere handelens omfang - der blev ikke skrevet regninger eller givet kvitteringer. Flere købmænd havde også betydelig omsætning af jyske strømper og fynske handsker, og de solgte videre til et stort område. De små købmænd rejste selv omkring til markederne for at finde købere til de varer, som bønderne havde leveret. Købmændene skabte derved forbindelse mellem vævere og forbrugere, og derved kan der meget vel være opstået et væsentligt element af afhængighed mellem væver og købmand. At definere afhængigheden nærmere er blot ikke muligt i dag. Der var forskelle fra tilfælde til tilfælde - det gjaldt på Flensborgegnen såvel som $\mathrm{i}$ Nordøstslesvig. ${ }^{85 a}$

\section{Husflid contra købetøj}

Den betydelige eksport af hjemmegjort tøj viser, at produkterne var værdsatte. De var solide og kunne ofte i det ydre måle sig med mere industriprægede importvarer. Mange beretninger fra datiden bekræfter, at menigmand fortrinsvis klædte sig i de hjemlige tøjer. Om Adsbøl-egnen skrev pastor Burchardi i 1792, at folk brugte det hjemmegjorte lærred og især uld- og halvuldent tøj, »og mangen husmoder regner sig det for en ære at klæde sig og sine i disse produkter af egen flid«. Den begrænsede overskudsproduktion, som kom til salg, fandt let købere. ${ }^{86}$

Fra Haderslev amt berettes tilsvarende i 1778: "Bønderne her i amtet, dvs. mændene klæder sig kun sjældent og til nød til deres bryllup i blå, grønne, også sorte fremmede tøjer, til 3-6 mark pr. alen. Og i så fald bruger de dem gennem hele livet. Men normalt klæder de sig $\mathrm{i}$ indenlandske, hjemmegjorte uldne, blandede uld- og hørtøjer, også garvet læder til veste, brystdug og benklæder. De rene uldtøjer kaldes vadmel og koster 8-10 sk [pr. alen] eller mere, de blandede stribede eller tærnede tøjer af uld og hør hedder tøssel eller tressel og koster 6-8 sk pr. alen. Disse to typer uldne og blandede tøjer bærer kvinderne; desuden bruger de almindelig sirts, kattun, serge, kalemanke, fries, flanel, uld- og silkedamask og taft, kammer- og netteldug, floret og stribede glatte silkebånd [dvs. importerede varer] ... Uld- og hørstrømper, lærred og dynevår og kniplinger er gemenlig indenlandske « ${ }^{87}$

Der var altså et vist forbrug af ikke-hjemmegjorte tøjer, især blandt kvinderne. Og dette behov for fremmede tekstiler blev dækket af købmændene og tilrejsende handlende. I købmændenes boder bugnede hylderne med utallige 
typer fremmede stoffer. ${ }^{88}$ Købmænd og kræmmere var forpligtet til at aftage en vis mængde varer årligt fra indenlandske fabrikker. Sidst i 1700-årene var det især fabrikkerne i Frederiksstad, Husum, Rendsborg, Neumünster og

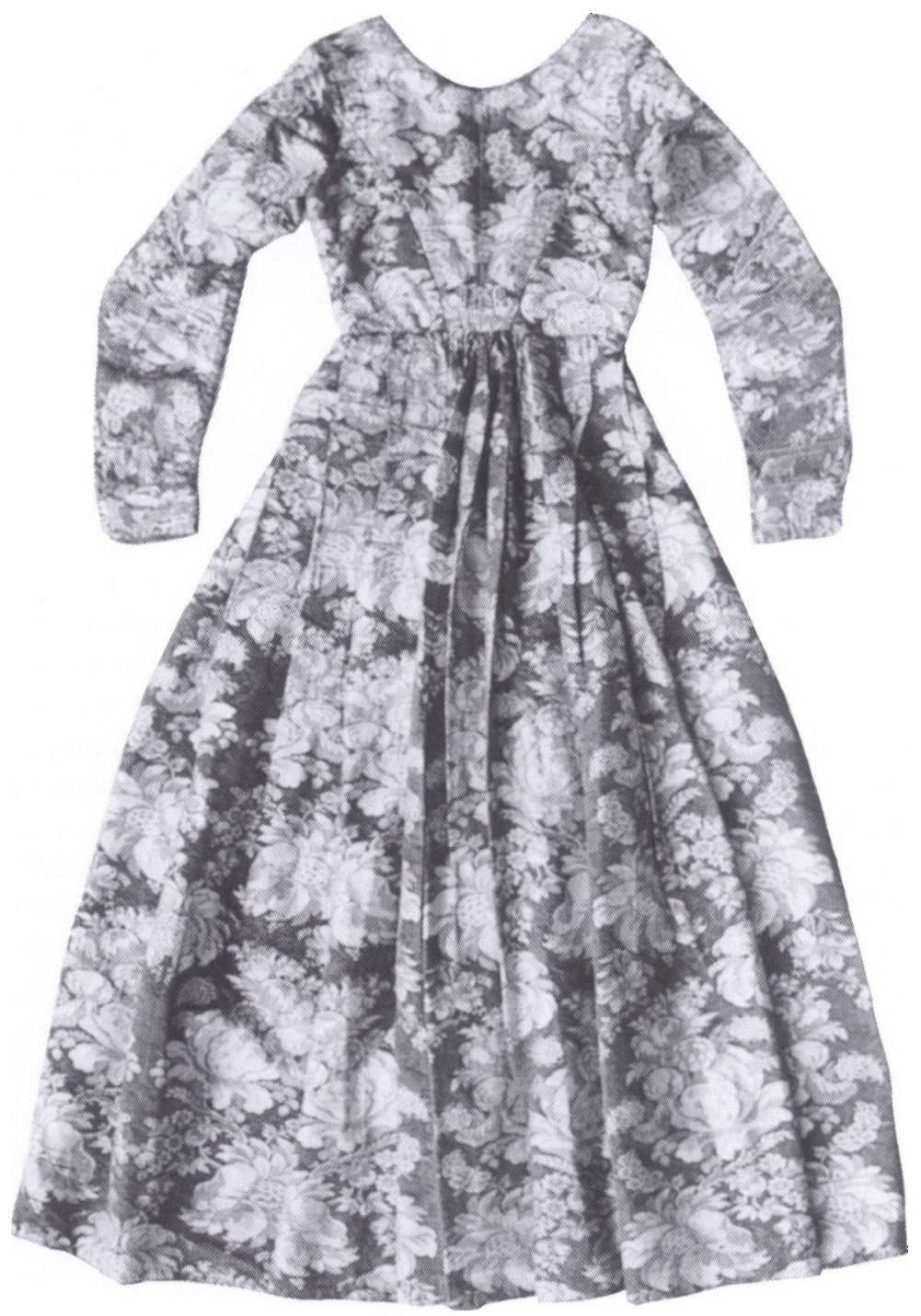

I velhavende bondehjem var der råd til at indkobe fremmede luksustojer til sarlig højtidelige lejligheder. Brudekjolen her fra gården Bygvrå i Fjelstrup sogn stammer fra et bryllup år 1800. Den er syet af rokokostof fra 1700-tallets midte. Gengivet efter Gudrun Andresen og Klara Sorensen: Fra Silkesko til Bondens Bo, 1988 s. 27. 
Glückstadt, som nød godt af denne tvungne afsætning. Udenlandske varer hentede købmændene på de årlige Lætare- og Dionysi-markeder i Flensborg, hvor utallige fremmede handlende mødte op med deres varekister. Større tekstilkøbmænd lod de fine sager indforskrive direkte fra Hamborg, Altona eller Holland. Enkelte rejste årligt til messe i Braunschweig. ${ }^{89}$ Importen var ganske belastende for handelsbalancen. I hertugdømmet Slesvig tegnede Flensborg sig for næsten hele indførslen. ${ }^{90}$ De fine fremmede stoffer kunne liebhavere også få på de mange årsmarkeder rundt om i byerne, hvor larredshandlere fra Flensborg, Hamborg, Frederiksstad osv. opslog deres boder. Endelig var der omrejsende handelsfolk, ikke mindst jøder, som rejste omkring på landet og gik de mere fastboende handlende i næringen.

Som nævnt var de sarte og dyre importtekstiler dog ikke hverdagsgods hos »almuen«, og langt op i 1700-årene kunne deres afsætning næppe måle sig med, hvad der gjaldt for de hjemlige produkter. De gode konjunkturer sidst $\mathrm{i}$ århundredet bragte måske tingene lidt $\mathrm{i}$ skred. Det blev nu muligt at ofre mere på klædedragten, og selvfølgelig har mange kastet deres øjne på eksotiske varer. Alligevel blev en del af den mere kræsne efterspørgsel dækket ved forfinelse af de hjemlige varer. At de hjemmevævede tøjer kunne gøres mere indbydende, og således også tilfredsstille en ny, rigere periodes krav, fremgår bl.a. af Øster Løgum præsten Peter Kiers beretning om den ændrede levemåde omkring år 1800. Velstanden viste sig bl.a. i den overflødighed af sengetøj, som fandtes hos bønderne. "Fornemmelig udmærkede han [bonden] sig $\mathrm{i}$ Klæder. Vel var de fleste af hjemmegjorte Tøyer, men disse vare fine og farvede med ret kostbare Farver, saasom blaae og grønladne. Men Qvinderne havde ogsaa Klæder af Silke og Bomuld, virkelig ret kostbare. ... Dog maae siges at mangfoldige $i$ det vestre Sogn endnu vare som tilforn klædte i musegraa Vadmelskjoler og tildeels Skindbuxer $\ll{ }^{92}$ De gode tider øgede således markedet for importstoffer - men stimulerede samtidig den hjemlige produktion. Husfliden satte sin rigeste blomst netop i sin slutfase, i 1800-årene lige inden maskinerne gjorde den overflødig. De lokale vævere søgte at tage kampen op mod de fabriksfremstillede modevarer. Farverne brugte finere kulører, og vævningen blev forfinet. Intet tyder på, at husfliden var på retur ved udgangen af 1700-tallet - snarere tværtimod. Dette gælder i Sønderjylland lige så vel som i Kongeriget. ${ }^{93}$

\section{Sønderjyderne mere flittige end andre danske?}

Vi har nu fulgt de flittige og vindskibelige sønderjyder og nogle af deres produkter på vej fra væven til forbrugeren. Fliden var altså en realitet. Men 
var sønderjydernes flid noget særligt, var deres søstre og brødre i de danske provinser, især på Sjælland og Lolland, reelt mindre flittige, ja dovne, således som det blev påstået? Dette spørgsmål vil vi prøve at nærme os her til afslutning.

Et foreløbigt svar finder vi hos Erik Pontoppidan i et værk fra 1759. Den lærde biskop beretter, at bondestanden i Danmark næsten helt selv forsynede sig med uldne og linnede varer. "Hver landsby har sine manufakturer, skønt de ikke anses derfor. I mange, ja vel i de allerfleste, særdeles jyske og fynske bønderhuse væves enten uldent eller linnet. Følgelig kan vore købstadsfabrikker ikke have nogen synderlig debit eller afsætning paa sine varer udenfor stæderne .... ${ }^{94}$

Denne vurdering kan underbygges med konkrete eksempler fra hele landet. På Bornholm voksede betydningen af hvergarns- og hørvævning stærkt fra 1720 'erne. I næsten alle gårde og også i byerne var der væve, og skipperne tog anselige mængder hvergarn og linned med til salg i København og Helsingør. ${ }^{95}$ På Sjalland og Lolland lagde hoveriet beslag på de fleste kræfter, og der blev næppe fremstillet så mange tekstiler til salg som andetsteds - dog nok til at dække befolkningens behov. På Fyn var overskudet til salg større. En særlig blomstring opnåede husfliden i dele af Østjylland. Her var der let adgang til hør, importeret fra Østersøområdet, og den gode jord muliggjorde en ret omfattende høravl. Fra Randers, Ribe og Ålborg blev der udført betydelige mængder lærred især til København - $\mathbf{i}$ et omfang som sikkert overgik den østslesvigske eksport. Produktionen havde i nogen grad karakter af forlagsvirksomhed. Byernes købmand skaffede hørren og formidlede varerne afsat på de fjerne markeder. ${ }^{96}$ Husflid både til eget behov og til salg var kort sagt vidt udbredt nord for Kongeåen. Her som andetsteds var disse sysler en betingelse for at overleve i en karrig verden. Overalt fik bondestanden i 1700tallet de fleste daglige uld- og lærredstøjer fra den hjemlige husflid, og undgik derved mange pengeudgifter til køb af tekstiler fra byerne. Denne sparsommelighed var nødvendig, hvis landboerne skulle kunne bære skatter og andre uomgængelige kontante byrder. Sønderjyderne var med andre ord, hvad angår husfliden, ikke noget enestående.

\section{Slutord}

Eksporten fra Nordøstslesvig til København var altså ikke et specielt sønderjysk fænomen. Vi møder den i Nørrejylland, på Fyn og Bornholm. Der var ligheder tværs over Kongeåens $\mathrm{i}$ øvrigt så dybe skel. I hele monarkiet var binæringerne - deriblandt fremstilling af tekstiler - nødvendige for bondesam- 
De professionelle farvere var ikke ene om at give tojerne de onskede kulorer. Også i bondehjemmene blev der farvet, og viden om den fine kunst blev videregivet mundtligt og skriftligt. Denne lille bog fra 1785 giver gode rdd om at farve uld- og linnedgarn i alle slags farver - rod, brun, gul, bld, gron. sort, purpurviolet, hver iflere varianter. Et drhundrede senere var den gamle kunst tilsyneladende ved at gà i glemme - derfor bemarkningen nederst fra 1884: "Om hundrede Aar er ei Alting glemt'" LA Ab Forskelligt nr. 113.

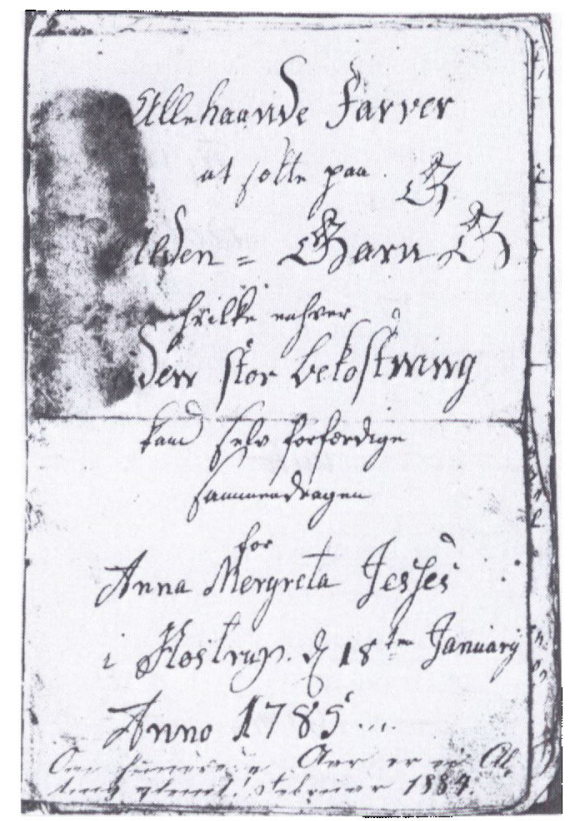

fundet, når det gjaldt om at skaffe overskud til betaling af skatter og uundværlige importvarer som f.eks. jern, tjære, salt, krydderier osv. ${ }^{97}$ Men naturligvis var der også forskelle på egnene nord og syd for Kongeåen. De slesvigske bønders frihed og den ret ekstensive landbrugsdrift med særlig vægt på studeavl kan have givet hjemmevæuningen særlig gode vilkår $\mathrm{i}$ mange hjem $\mathrm{i}$ Østslesvig, både i bondegårde og især i huse. ${ }^{98}$

Erhvervsvæverne betød desuden mindre i Sønderjylland end nord for Kongeåen. I Haderslev herred var der således i 1737 i hver landsby så mange væversker blandt bondekoner og ugifte piger, at de kunne dække byens behov for uld- og hørtøj. Folk havde derfor ikke nødig at lade væve i købstaden. I Tyrstrup herred var der også i »de fleste landsbyer af bondekoner og døtre 1, 2 eller 3, som kan væve det nødvendige almindelige lærred og uld til sig selv og deres naboer. Men af mandsvævere er der $i$ hele herredet ikke mere end 4$5 \ll{ }^{99}$ Væveriet foregik med andre ord i det alt væsentlige som husflid eller binæring og i mindre grad som erhvervsmæssigt væveri.

Modsat var husfliden nok mere begrænset i nogle egne af Kongeriget, især i den østlige del, hvor landbrugsarbejdet lagde mere beslag på bondens arbejdskraft, og hvor der rådede hoveri og stavnsbånd. Professionelle vævere indtog $\mathrm{i}$ disse egne en mere fremtrædende plads, således på Sjælland og Lolland. På Fyn og i dele af Østjylland derimod lignede forholdene mere det 
billede, vi kender fra Nordøstslesvig. Den gode jord gav også her mulighed for hørdyrkning, og især var den lette adgang til import af hør fra Østersøbyerne en impuls for lærredsfremstillingen. Varerne fandt afsætning lokalt, noget gik til Norge, men især til København, for hvis "gemene almue og søfarende folk disse varer ere saa godt som umistelige «. ${ }^{100}$

Husfliden levede videre ind i 1800-årene, og hørdyrkningen fik en tid øget betydning. Importvanskelighederne under Napoleonskrigene og de efterfølgende års økonomiske vanskeligheder motiverede til at lægge vægt på den hjemlige høravl, og Landhusholdningsselskabet gjorde hvad det kunne for at fremme denne udvikling. Men opgangen var tidsbegrænset. Sidst $\mathrm{i}$ århundredet gik hørdyrkningen atter tilbage, indtil den næsten forsvandt fra 1890 'erne de fleste steder. Kun i særlig vanskelige perioder, således krigsårene 1914-18 og 1940-45, er hørdyrkning senere taget op igen på traditionel vis.

Meget havde ændret sig på dette tidspunkt. I takt med stigende velstand havde den købstadsprægede mode nu vundet indpas i landbefolkningen. I 1844 kunne pastor H.N.A. Jensen i Gelting i Angel klage over angelboernes stadig mere krævende vaner: "Snart vil man ikke se dem mere, de gamle ærværdige skikkelser, mændene med den hjemmegjorte blå frakke eller kamisol uden krave, med en række blanke knapper ...; næppe ser man mere, endnu kun ved ældre kvinder, hue og tørklæde af hjemmegjort tøj. Alt får nu byagtigt tilsnit, og udenlandsk skal stoffet være, måske købt billigere, men også mindre holdbart ${ }^{101}$

Sådan vandt den begyndende industris produkter frem, omend det gik langsomt $\mathrm{i}$ de mere magre egne ... "ssaavidt jeg har kunnet erfare, bruges her langt mere hjemmegjorte Klæder end i de mere velhavende Egne østerude«, skrev H.F. Feilberg i 1863 om hedeegnen vest for Flensborg. ${ }^{102}$ Hør og uld blev spundet $i$ mange hjem endnu en tid lang. Men fyrre år senere var også det næsten en saga blot. ${ }^{103}$ Fåreholdet svandt nu kraftigt ind, samtidig med det intensive landbrugs sejrsgang, og hørdyrkning gik af brug de fleste steder. Spinding blev en uddøende, gammeldags specialitet: "Tjenestefolkene vil ikke længere spinde, og landboerne køber nu mere iøjnefaldende, omend lettere stoffer«, hedder det fra Ensted sogn omkring år 1900. ${ }^{104}$

Hjemmevævningen gik af brug. På Løjt kunne der endnu i 1830'erne berettes om udbredt lærredsvævning i alle byer - alene fra den lille $ø$ Barsø blev der solgt 1.500-2.000 alen hør- og blårlærred årligt. I 1906 var både hørdyrkningen og væuningen et fortidigt fænomen. ${ }^{104 a}$

Længst holdt hjemmevævningen sig nok på Sundeved - et af centrerne for den gamle uldvævning. I væveren Th. Kaufmanns barndom i Felsted i 1880 'erne var der vistnok endnu en væv $i$ brug $i$ hver af sognets gårde. ${ }^{105} I$ Rinkenæs var en skrædderkone som vævede gode, solide lagner, håndklæder 


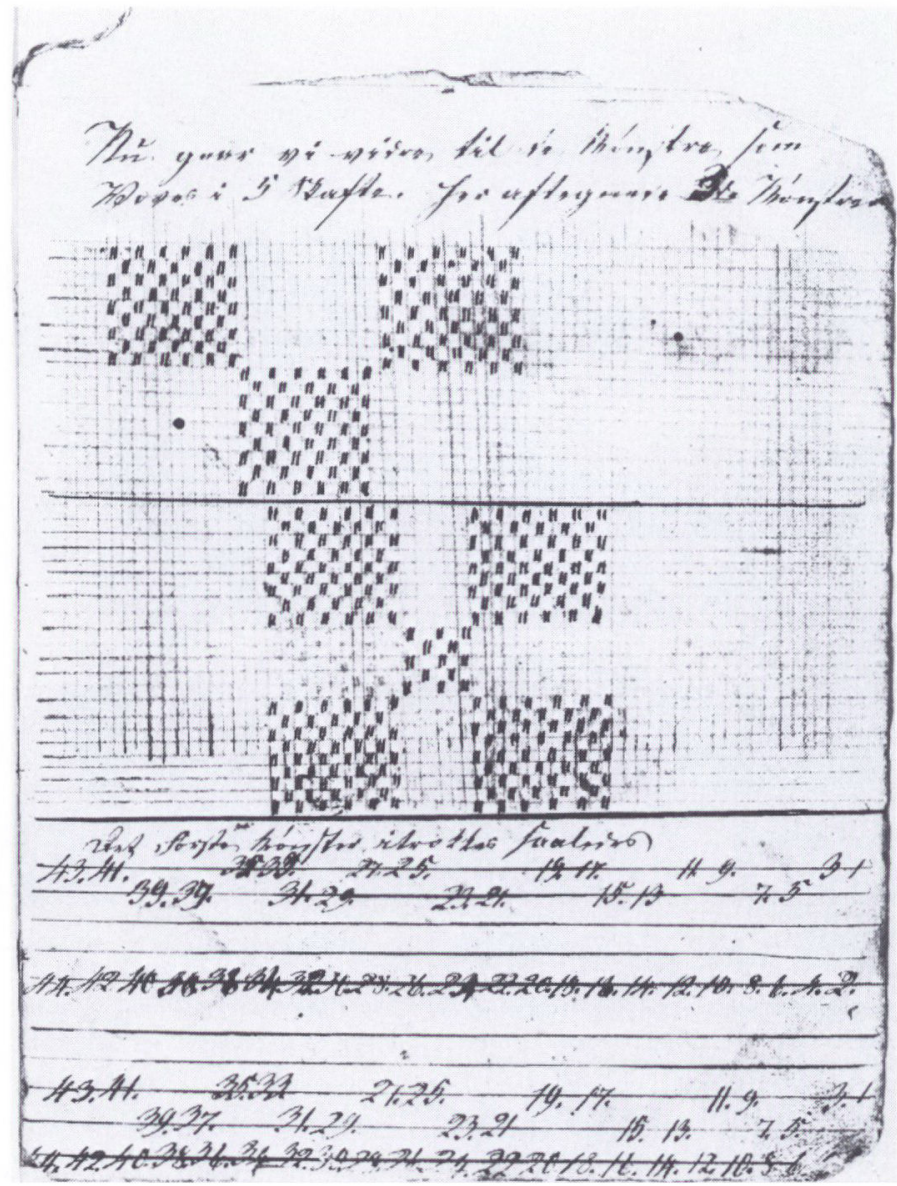

Monsterboger gav anvisning $i$ vavningens vanskelig kunst. Her er vist et eksempel på monster $i$ "Tosøll med Linnet Trendgarn og ulden Islatt«. Proven stammer fra den hdndskrevne "Efterretning om det Simple og Daglige Vaveri til Brug for Hanna Maria Andreasen. Skreven i Gabel Aaret 1838 af J.A.Brichu. LA Ab Forskelligt nr. 114.

og bordduge ikke et særsyn o. 1870. Men traditionen blev ikke ført videre af de unge piger. "Nej, nu bliver det for galt, nu får de unge piger cykler, de skulle hellere have et spindehjul«, kunne en af de gamle udtale sidst i århundredet. ${ }^{106}$

Disse år betegnede sidste akt for det hjemmegjorte tøj. Husfliden ebbede ud, og professionelle vævere overtog i denne afsluttende fase den sidste rest af væuning på landet. De mandlige vævere kom nu frem og fik afgørende 


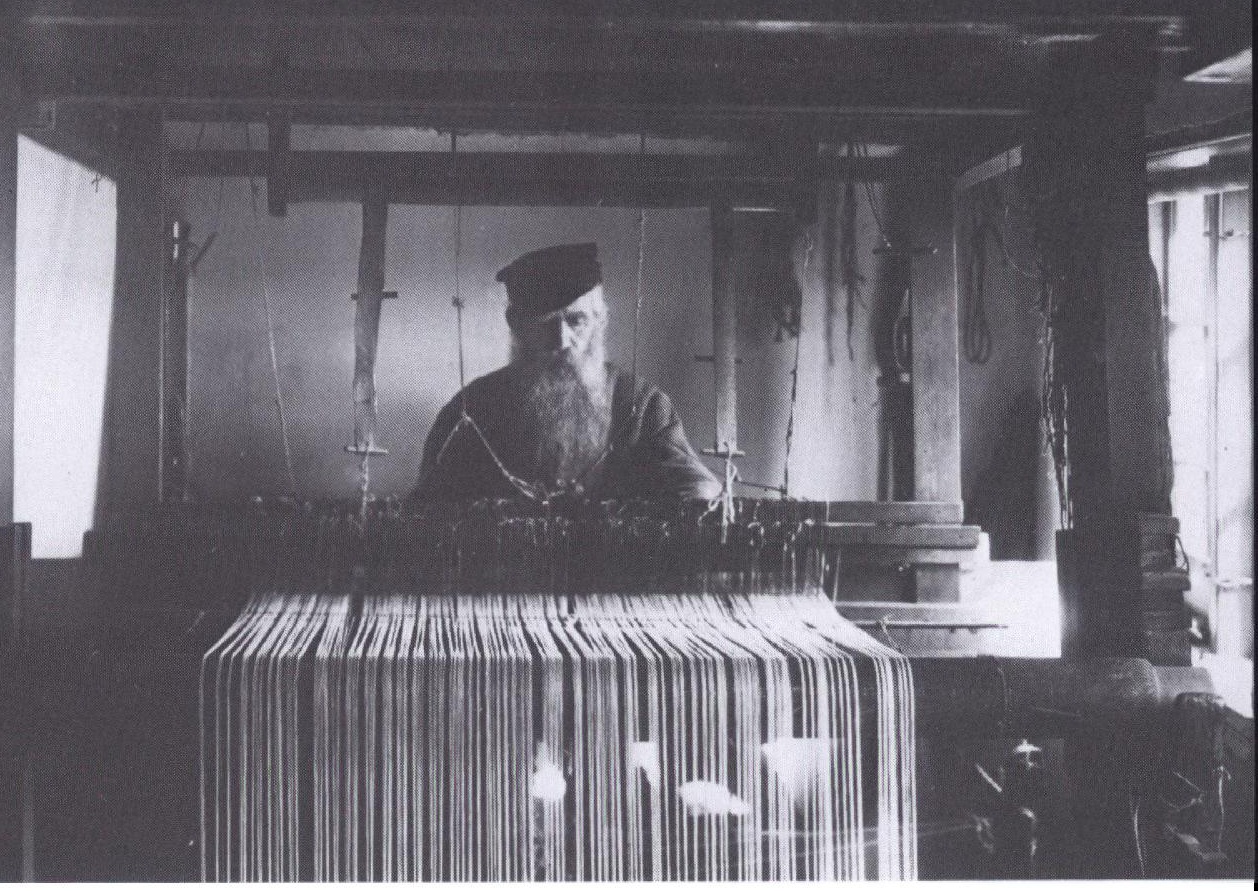

Sidst $i$ 1800-arene fik erhvervsvaverne oget betydning, og de trangte gradvis hjemmevavningen $i$ defensiven. Her er Jens "Donnerwetter" Christensen i Klosteret $i$ Flensborg fotograferet ved vaven, formentlig omkring år 1900. Man ser tydeligt kadetrådene i tojets langderetning og overst skafterne med de såkaldte soller, Fot. Th. Thomsen, Flensborg. Dansk Centralbibliotek for Sydslesvig.

betydning. Det er karakteristisk, at de meget fine mønsterbøger der kendes fra $1800-1840$ 'erne oftest er fra mandlige vævere. ${ }^{107}$ De erhvervsmæssige vævere klarede sig langst i Haderslev, Aabenraa og Sønderborg amter - altså netop i de områder, hvor husfliden havde været mest livskraftig. Den 1. Verdenskrig betød en sidste renæssance for landsbyvæverne - men fristen var kortvarig den moderne fabriksindustri og dens produkter var kommet for at blive, og over for den konkurrence måtte husfliden bukke under. ${ }^{108}$

Vi har nu fulgt nogle former for husflid gennem et langt tidsrum, fra blomstring til forsvinden. Nået hertil må det fremhæves, at husflidens betydning i det gamle landbrugssamfund vanskeligt kan overvurderes. Helt ind i 1800årene var overskuddet fra den primære landbrugsdrift $\mathrm{i}$ mange egne kun begrænset, $\mathrm{og}$ ofte svingende. For både bønder og især for småfolk var det derfor helt nødvendigt at supplere med andre indtægter. I krisetider var det 
sikkert ikke mindst binæringerne, som holdt folk oven vande. Pastor Kier fra Øster Løgum udtrykker det klart i beskrivelsen af sit sogn i 1820'ernes vanskelige år: I disse tider kunne hovedindtægterne fra korn, kvæg og tørv i det magre sogn kun med nød og næppe dække leveomkostninger og skatter husfliden var derfor den redningsplanke, som bar alle andre udgifter. De såkaldte småfolk måtte alene nære sig af husflid og håndværk. ${ }^{109}$

Tilsvarende var forholdene i Kongeriget. Hvor der kan påvises rigdom i bondehjem, kan bl.a. husfliden ofte anses for en medvirkende årsag. ${ }^{110}$ Uden husfliden er det følgelig ikke muligt at tegne et dækkende billede af tidligere tiders landbrugssamfund. Landbefolkningens liv var andet og mere end blot korn- og kvægavl. Husfliden var en integrerende del af dagligdagen og af det økonomiske livsgrundlag. Og blandt de mange forskellige former for binæringer var forarbejdning af uld og hør og tilvirkning af tekstiler nok den allermest udbredte form for husflid på landet.

Skipperne som stævnede ud fra Aabenraa og Haderslev med tekstiler i lasten var sammen med de omrejsende handlende, som drog fra markederne belæsset med lærred og tussel udtryk for tekstilforarbejdningens betydning. De er den top af isbjerget, som rager op af vandet. Under dem gemmer sig den omfattende produktion og omsætning af tekstiler, som har været emnet for denne skildring.

\section{Bilag 1}

Tekstiludforsel ifg. retsprotokollerne

\begin{tabular}{|c|c|c|c|c|}
\hline Haderslev & hør- og blårlærred & tosel & dynevår & uldtøj \\
\hline 1745 juli-dec. & $\begin{array}{c}14.785 \text { alen } \\
43 \text { stk. }\end{array}$ & 340 alen & 32 alen & 1.478 alen \\
\hline 1746 & $\begin{array}{c}5.320 \text { alen } \\
9 \text { stk. }\end{array}$ & & 70 alen & $\begin{array}{c}36 \text { alen } \\
2 \text { stk. }\end{array}$ \\
\hline 1751 & $\begin{array}{c}5.000 \text { alen } \\
9 \text { stk. }\end{array}$ & & & $\begin{array}{r}200 \text { alen } \\
3 \text { stk. }\end{array}$ \\
\hline 1752 & $\begin{array}{l}26.110 \text { alen } \\
34 \text { stk. }\end{array}$ & 66 stk. & 56 alen & $\begin{array}{l}1.327 \text { alen } \\
25 \text { stk. }\end{array}$ \\
\hline 1754 & $\begin{array}{c}8.862 \text { alen } \\
8 \text { stk. }\end{array}$ & 98 stk. & $\begin{array}{l}250 \text { alen } \\
1 \text { stk. }\end{array}$ & $\begin{array}{c}772 \text { alen } \\
7 \text { stk. }\end{array}$ \\
\hline 1755 & 31.026 alen & $\begin{array}{c}2.253 \text { alen } \\
92 \text { stk. }\end{array}$ & 691 alen & $\begin{array}{r}438 \text { alen } \\
9 \text { stk. }\end{array}$ \\
\hline 1756 & 28.654 alen & 60 stk. & 942 alen & $\begin{array}{l}220 \text { alen } \\
8 \text { stk. }\end{array}$ \\
\hline 1757 & $\begin{array}{l}20.267 \text { alen } \\
63 \text { stk. }\end{array}$ & 58 stk. & 668 alen & $\begin{array}{c}383 \text { alen } \\
13 \text { stk. }\end{array}$ \\
\hline
\end{tabular}

Kilde: LA Åb Haderslev bys retsprotokoller 1745-57 (nr. 23-25)

Anm.: Tekstiler fra vævere i Haderslev by er medtaget, drejl dog ikke. 


\section{Bilag 2}

Tekstiludforsel iflg. retsprotokollerne

\begin{tabular}{|c|c|c|c|c|c|}
\hline Aabenraa & $\begin{array}{l}\text { hør- og } \\
\text { blårlærred }\end{array}$ & $\begin{array}{l}\text { trykt eller } \\
\text { farvet lærred }\end{array}$ & tosel & dynevår & $\begin{array}{l}\text { uldtøj (uld- og } \\
\text { lærredstøj) }\end{array}$ \\
\hline 1742 & 10.530 alen & 230 alen & & & 224 alen \\
\hline 1745 & 8.421 alen & 93 alen & & & $\begin{array}{l}407 \text { alen }+ \\
147 \text { alen uldtøj }\end{array}$ \\
\hline 1747 & 4.491 alen & & & & \\
\hline 1752 & 14.219 alen & & 2 stk. & & 438 alen uldtøj \\
\hline 1755 & 12.722 alen & 70 alen & 154 alen & 340 alen & \\
\hline 1756 & 11.355 alen & $\begin{array}{l}580 \text { alen stribet eller } \\
\text { trykt lærred }\end{array}$ & & 47 alen & 167 alen uldtøj \\
\hline 1757 & 14.337 alen & 388 alen trykt larred & & & 44 alen uldtøj \\
\hline 1761 & 27.855 alen & 36 alen & & 46 alen & $\begin{array}{l}112 \text { alen uldtøj } \\
+2 \text { stk. }\end{array}$ \\
\hline 1762 & 22.101 alen & & & & \\
\hline 1763 & 14.752 alen & 25 alen trykt lærred & & & 85 alen uldtøj \\
\hline 1764 & 14.863 alen & 100 alen trykt lærred & & & 40 alen uldtøj \\
\hline 1765 & 18.007 alen & & & 62 alen & 512 alen \\
\hline 1767 & 14.776 alen & & & & \\
\hline 1768 & 20.967 alen & & & 52 alen & \\
\hline 1770 & 19.420 alen & & & & 14 alen uldtøj \\
\hline 1771 & 17.274 alen & 20 alen & & & \\
\hline 1772 & 12.722 alen & & & & \\
\hline 1773 & 7.929 alen & $\begin{array}{l}14 \text { alen blå-rød- } \\
\text { ternet lærred }\end{array}$ & & & \\
\hline 1775 & 5.620 alen & & & & 266 alen uldtøj \\
\hline 1776 & 12.817 alen & & & & 10 alen uldtøj \\
\hline 1777 & 16.589 alen & 40 alen trykt larred & & & \\
\hline 1778 & 9.495 alen & 200 alen & & & \\
\hline 1779 & 12.573 alen & & & & 50 alen uldtøj \\
\hline 1780 & 23.161 alen & & & & \\
\hline 1781 & 14.060 alen & $\begin{array}{l}3.000 \text { alen blå- og hvid } \\
\text { lærred }\end{array}$ & & & \\
\hline 1782 & 9.168 alen & 2 stk. trykt lærred & & & \\
\hline 1783 & 6.269 alen & & & 64 alen & \\
\hline 1784 & 8.010 alen & 10 stk. trykt lærred & 6 stk. & & \\
\hline 1785 & 10.213 alen & 800 alen & & & \\
\hline 1786 & 7.096 alen & 20 alen & & 60 alen & 76 alen uldtøj \\
\hline 1787 & 13.439 alen & 28 alen & & & $11 \frac{1}{2}$ alen uldtøj \\
\hline 1788 & 7.960 alen & & & & \\
\hline 1789 & 12.161 alen & & & & \\
\hline 1790 & 11.601 alen & & & & \\
\hline
\end{tabular}

Kilde: LA Åb Aabenraa bys retsprotokoller 1742-90 (nr. 829-876) 


\section{FORKORTELSER}

Komm. koll. Kommercekollegiet

LA Åb Landsarkivet i Aabenraa

Prov. Ber. Schleswig-Holsteinische Provinzialberichte

QuFGSH Quellen und Forschungen zur Geschichte Schleswig-Holsteins

RA Rigsarkivet

Rtk. Rentekammeret

SJy MSkr Sønderjysk Månedsskrift

SJy Årb Sønderjyske Årbøger

ZSHG Zeitschrift der Gesellschaft für Schleswig-Holsteinische Geschichte

\section{NOTER OG HENVISNINGER}

1. LA Åb Åbenrå bys retsprotokol 1767 20. juni. RA Slesvigske toldregnskaber Åbenrå 4, 1767.

2. RA Slesvigske toldregnskaber Haderslev 4, 1753.

3. Johan Arndt Dyssel: Forsøg til en Indenlands Reise, 1774 s. 68, 71 og 102.

4. P. Rhode: Samlinger til Haderslev-Amts Beskrivelse, 1775 s. IX, XII og XIII.

5. Erich Pontoppidan: Den Danske Atlas bd. VII, 1781 s. 109f. August Niemann: Handbuch der schleswig-holsteinischen Landeskunde I, 1799 s. 14, 39, 59.

6. L.M. Wedel: Indenlandske Rejse. Første Hefte, 1803, s. 77f, Andet Hefte, 1803 s. $46 f$.

7. Knud Aagaard: Beskrivelse over Torning Lehn, 1815 s. 126, 157, 168.

8. L.W. Wedel, anf. arb. Andet Hefte, 1803 s. 68.

9. RA Komm. koll. ty. sekr. Jr. A nr. 253 (1737).

10. Haderslev rảdstuearkiv Cod. 42, relationsprot. $17397 / 1$.

11. LA Åb Haderslev amt Komm. koll. sager, Østeramt 1767-82, sag nr. 132 og Slesvigske registratur nr. 87, indbr. fra Gram hrd. 1777.

12. RA Komm. koll. nr. 1562, indbr. fra Åb.-Løgumkloster amter 1809.

13. Kulturhistorisk Leksikon for nordisk middelalder bd. X, 1965 sp. 578-586.

14. Bjørn Poulsen i SJy Årb 1989 s. 110.

15. Danske Vider og Vedtægter III, 1913-20 s. 11. Knud Aagaard, anf. arb. s. 167. - Hanne Frøsig Dalgaard: Hør som husflid (1980) s. 35.

16. Gottorp amtsregnskab 1613-14, venligst meddelt af Peter Kr. Iversen.

16a. Prov. Ber. 1790 s. 502 . - RA Komm. koll. pk. 832, jr. 59/1778.

17. Sønderjyske Stednavne, 1933-44, passim

18. RA Komm. koll. ty. sekr. Jr. A nr. 253 (1737). - Haderslev rådstuearkiv XIX E 1, 1739 7/1.

19. Gram gods. Revisionsprotokol 1761. Udg. 1989 ved Peter Kr. Iversen.

20. LA Áb Haderslev amt Komm. koll. sager Østeramt $1767-82$ (pk. 374) 1775 24/1.

21. RA Komm. koll. ty. sekr. nr. 204.

22. RA Komm. koll. ty. sekr. Jr. A nr. 20 (1735). - LA Åb Åbenrå amt C II' nr. 110 (1738-39). - Ábenrå byarkiv nr. 155,1 (1738 22/11). - Paul Hansens dagbog i LA Åb privatarkiv nr. 265, jvfr. SJy Årb 1933 s. 176-190.

23. LA Åb Åbenrå amt C II ${ }^{1}$ nr. 113.

24. Peter Kier: Atlas over Øster Løgum sogn, udgivet ved Tage Morsing, Aabenraa 1987 s. 42 og 46. I tabellen side 46 er fejlagtigt anført "tdr« hør. Det rigtige er »skapper« og »lispund «.

25. Hanne Frøsig Dalgaard: Hør som husflid, 1980 s. 35. - Paul v. Hedemann-Heespen i ZSHG bd. $48 \mathrm{s.} 78$.

26. Peter Kier anf. arb. s. 38.

27. RA Komm. koll. 2121 III.

28. RA Slesvigske toldregnskaber Haderslev 4, Åbenrå 2,4, Sønderborg 3. 
29. se f.eks. salg til Enge (Prov. Ber. 1791 hft. 4, s. 11), Valsbel m.v. (H.F. Feilberg: Fra Heden, Slesvigske Provindsialefterretninger Ny rk. bd. 4, 1863 s. 271). - Jvfr. H.V. Gregersen i SJy Årb 1958 s. 76 og 80.

30. Se f.eks. stadelister i Haderslev rådstuearkiv XIX E 3.

31. RA Slesvigske toldregnskaber Haderslev 1 og Åbenrå 1. - Jvfr. Prov. Ber. 1790 s. 500.

32. LA Åb Åbenrå byarkiv nr. 175a (1735), jvfr. SJy MSkr. 1937 s. 162 (J. Hvidtfeldt).

33. RA Slesvigske toldregnskaber Åbenrå 1 og 4. - H.V. Gregersen i SJy Årb 1949 s. 64 fog 81. - Georg Hanssen: Statistische Forschungen über das Herzogthum Schleswig Hft. 1, 1832 s. 53 (om Ballum).

34. RA Komm. koll. ty. sekr. Jr. A nr. 253 (1737). - RA Slesvigske toldregnskaber Haderslev 4, skibslister 1767 og 1769. - Haderslev rådstuearkiv XIX E 1, kræmmerlister (Lor. Musmann).

35. Georg Hanssen: Statistische Forschungen über das Herzogthum Schleswig, II, 1833 s. 8.

36. Haderslev rådstuearkiv XIX A (kasse 364) 1765 24/8 til Rtk.

37. Aug. Niemann: Landeskunde, 1799 s. 103 og 116. - Georg Hanssen anf. arb. I, 1832 s. 54 . Sonderjyllands Historie, bd. 3, 1940-42 s. 350 og 445 .

38. RA Komm. koll. ty. sekr. Jr. A nr. 253 (1737).

39. Knud Aagaard: Veiledning ved en Gaards Drift i Hedeegne, 1811 s. 126. - samme: Beskrivelse over Tørning Lehn, 1815 s. I61f. - Jvfr. Georg Hanssen anf. arb. II, 1833 s. $65 f$. - LA Áb Haderslev amt Komm. koll. Osteramt pk. 377, indbr. fra Gram hrd. 1792.

40. Knud Aagaard anf. arb. 1815 s. 160 f.

41. Prov. Ber. 1797 hft. 2 s. 133 (Skobøl). - Prov. Ber. 1791 hft. 4 s. 11 (Enge). - Prov. Ber. 1793 hft. 4 s. 83 (Angel). - Prov. Ber. 1793 hft. 5 s. 162ff. (Hütten). - Niemann anf. arb. 1799 s. 149, 356, 385, 389, 379, 439, 488. - Bjørn Poulsen: Land-By-Marked. To økonomiske landskaber i 1400-tallets Slesvig. Flensborg 1988 s. 111 (Husum-egnen).

42. Fritz Hähnsen: Die Entwicklung des ländlichen Handwerks in Schleswig-Holstein, 1923 (QuFGSH bd. 9) s. 124f.

43. LA Ab Haderslev amt Komm. koll. Vesteramt 1790-1817, pk. 382, 1790

44. LA Ab Haderslev amt Slesvigske registratur 87, 1776.

45. LA Åb Haderslev amt Slesvigske registratur 87, 1777 - ibid. Komm. koll. Østeramt pk. 377, 1792.

46. LA Åb Haderslev amt Komm. koll. Østeramt pk. 374, 1767-82 samt pk. 375-377.

47. LA Áb Åbenrå amt 2. v. Schmettows arkiv Gen. Komm. koll. sager 1787-99, pk. 296, årene 1787-98.

48. LA Áb Åbenrå amt v. Schmettows arkiv Komm. koll. sager 1776-86, pk. 266, 1776 28/12.

49. RA Komm. koll. nr. 1562, indbr. fra Øster Logum 1808-09.

50. RA Komm. koll. ty. sekr. Jr. A nr. 20 (1735).

51. Prov. Ber. 1792 I s. 375 - ibid. 1792 III s. 337. - Claus Duus: Top.-hist. Darstellung der Halbinsel Sundewitt, 1836 s. 18, 28 og 30f. - RA Komm. koll. 1562, indbr. fra ÅbenråLøgumkloster amter 1809.

52. LA Åb Åbenrå bys retsprotokol 1787 23/5 (Stubbæk). - SJy Årb 1933 s. 187 (Paul Hansen).

53. Haderslev rådstuearkiv Cod. 42 , relationsprot. 1741 15/2, 16/6, 30/7. - RA Komm. koll. ty. sekr. Jr. A nr. 253 (1737).

54. RA Komm. koll. 1562 og 1566 A. - Jens Lampe: Farversmølle ved Åbenrå, SJy MSkr. 1963 s. 261-264.

55. Prov. Ber. 1792 I, 3. hft. s. 337, 375, bd. 2 s. 174-177. - LA Åb håndskriftsaml. nr. 45. M. Høier: Klovtoft bd. X om »æ Farregaard«.

56. LA Åb retsbetjentarkiver nr. 23-25 og 822-880.

57. Peter Kier: Atlas over Øster Løgum sogn, udg. ved Tage Morsing, 1987 s. 45.

58. SJy MSkr. 1953 s. 144.

59. J.H. Riis: Bidrag til Løjt Sogns Beskrivelse og Historie I s. 99, manus. i LA Åb.

60. Prov. Ber. 1792 I s. 375-377.

61. LA Åb Haderslev amt Komm. koll. Østeramt pk. 374, sag nr. 132, 1774 2/7.

62. ibid. nr. $157,177814 / 1$. 
63. LA Åb Haderslev amt Slesvigske registratur nr. 87. - Om Camerer se DBL ${ }^{2}$ bd. IV, $1934 \mathrm{~s}$. 491. - Th. O. Achelis: Haderslev i gamle Dage bd. 2, 1929 s. 256f. - Jvfr. Prov. Ber. 1790 s. 499-503.

64. Georg Hanssen anf. arb. II, 1833 s. 32 . - Hähnsen anf. arb. s. 129.

65. Haderslev rådstuearkiv XIX E 3, 1718 5/4. - Achelis anf. arb. II, 1929 s. 195-200.

66. Haderslev rådstuearkiv Cod. 40, 1728 28/9.

67. Haderslev rådstuearkiv XIX E 1.

68. Huse i Haderslev bd. 1, 1982 s. 292. - Haderslev rådstuearkiv XIX E 1.

69. LA Åb Haderslev bys skifteprotokol bd. VIII, 1b. nr. 135. - Huse i Haderslev bd. 1, $1982 \mathrm{~s}$. 138. - Olav Christensen: Haderslev købstads ejendomme, 1974 s. 104-106. (manus i Haderslev byhistoriske arkiv).

70. LA A b Haderslev bys retsprotokoller 1745 26/7, 1746 18/4 og 1747 10/4.

71. Kilder til det folgende er, hvor ikke andet er angivet, retsprotokollerne for Aabenraa 1735-94 og for Haderslev 1745-58, jvfr. bilag 1-2 side 161-162.

72. Prov. Ber. 1792 I s. 375.

73. LA Åb privatarkiv nr. 265, Paul Hansen, Barsmark.

74. Som eksempler på de nævnte købmænds omtrentlige afsætning af hør- og blårlarred til København kan på baggrund af retsprotokollerne anføres følgende tal: Niels Jürgensen: 1749 5.644 alen, 17619.707 alen. - Diderich Diderichsen: 17421.980 alen. - Jacob Schwennesen: 176710.216 alen. - Simon Jensen: 17768.317 alen, 17779.712 alen.

75. Bornholmske Samlinger II. Rakke, 18. bind, 1985 s. 106-109.

76. LA Åb Åbenrå amt C II' nr. 168, 1765 .

77. LA Åb Åbenrå bys retsprotokol 1752 14/7.

78. LA Áb Haderslev bys retsprotokoller 1745-58 (lb. nr. 23-25).

79. Ellen Andersen: Danske dragter. Moden i 1700-årene (1977) s. 212.

80. RA Slesvigske toldregnskaber Haderslev 1.

81. RA Toldregnskaber Københavns toldbog fra fremmede steder 1733.

82. RA Slesvigske toldregnskaber Haderslev 5.

83. Om forlagssystemet i Danmark se Axel Nielsen (red.): Industriens Historie i Danmark bd. 2, 1943 s. $38-45$ (J.O. Bro Jergensen).

84. Jvfr. Fritz Hähnsen: Die Entwicklung des ländlichen Handwerks in Schleswig-Holstein, Kiel 1923 (QuFGSH bd. 9) s. 127 fremhæver, at husflidsvæveriet på landet ikke udviklede sig til hjemmeindustri eller forlagssystem, men forblev en overskudsproduktion.

84a. Prov. Ber. 1790 s. 500-503.

85. LA Åb Åbenrå byarkiv nr. 172, $177224 / 3$.

85a. RA Komm. koll. ty. sekr. pk. 825, jr. nr. 69/1774.

86. Prov. Ber 1792 I, 3. hft. s. $337 f$. - ibid. 1792 I s. $376 f$.

87. LA Åb Haderslev amt Komm. koll. Østeramt pk. 374 sag nr. 157, 1778 9/5.

88. Se som eksempler på inventarer over tekstilkøbmænds lagre skifterne efter Peter Raben, Haderslev, 1774 og Hans Rudolph Feddersen, sst., 1762, LA Åb Haderslev bys skifteprotokoller VIII og V.

89. LA Åb Åbenrå byarkiv nr. 172 og Haderslev rådstuearkiv XIX E 1. - Jvfr. H.V. Gregersen: Flensborgs, Haderslevs samt Frederiksstads kladehandlere ..., SJy MSkr. 1958 s. 119.

90. RA Komm. koll. nr. 2121 Martfelts papirer III. - Også en "ringe handelsby« som Aabenraa havde dog en vis indførsel. 1777 drejede det sig f.eks. om 60 alen atlask, 12 alen kamelot, 66 alen damask, 36 alen silkestof, 72 alen uldstof, 168 alen flonel, 138 alen frese, 298 alen boy, $31 / 2$ pd. kamelgarn, 402 alen lacken =klæde, 200 alen groft lærred, 200 alen farvet larred, 12 alen manchester, 30 rdl. huer, 48 alen rask, se RA Slesvigske toldregnskaber Åbenrå 1777.

91. Haderslev rådstuearkiv XIX E 3, stadelister.

92. her cit. efter G. Japsen: Det dansksprogede skolevæsen i Sønderjylland indtil 1814, $1968 \mathrm{s.}$ 257.

93. jvfr. Hanne Frøsig Dalgaard: Hør som husflid, 1980 s. 35 og 96. 
94. her cit. efter Axel Nielsen (red.): Industriens Historie i Danmark bd. 2, 1943 s. 11 (J.O. Bro Jorgensen).

95. Bornholmske Samlinger II. række 18. bind, 1985 s. 49ff.

96. Axel Nielsen (red.) anf. arb. s. 14-19, 38-41.

97. jvfr. Carsten Hess: Binæringer og husflid i 1800-årenes danske bondesamfund. Upubl. speciale. Kbh. 1974. For denne henvisning takker jeg Bjørn Poulsen, Flensborg.

98. Georg Hanssen: Statistische Forschungen II, Amt Hadersleben, 1833 s. 31 .

99. RA Komm. koll. ty. sekr. Jr. A nr. 253 (1737).

100. Axel Nielsen (red.): Industriens Historie i Danmark II, 1943 s. 13-19. (J.O. Bro Jørgensen).

101. H.N.A. Jensen: Angeln, 1844 s. 307.

102. Slesvigske Provindsialefterretninger bd. 4, 1863 s. 271.

103. Th. Kaufmann nævner $i$ "Minder og Tanker (1962), at der for 1900 endnu var bondekoner fra Sundeved, Als og Løjt og enkelte i Aabenraa, der spandt hør (s. 43-46). cf. Fritz Hähnsen, anf. arb. s. 135f.

104. Lars N. Henningsen: Ensted sogns historie, 1987 s. 171.

104a. Johs. v. Schröder: Topographie des Herzogthums Schleswig, 1837, I s. 85, 86, 470, II s. 325. - Henning Oldekop: Topographie des Herzogtums Schleswig, 1906.

105. Th. Kaufmann: Vævning i Lundtoft herred og på Sundeved, SJy MSkr. 1962 s. 9.

106. Alex Asmussen: Lidt erindringer om mit levnedsløb, Historisk Forening for Graasten by og egn, Arsskrift 1988 s. 44.

107. Venligst oplyst af museumspædagog Inge Adriansen, som takkes for kritisk gennemlæsning af artiklen. Samme tak gælder Anne-Helene Michelsen, Kolstrup.

108. Fritz Hähnsen anf. arb. s. 134-136.

109. Peter Kier: Atlas over Øster Løgum sogn, udg. ved Tage Morsing, 1987 s. 23, 30, 33, 38 og $44 f$.

110. jvfr. Det danske landbrugs historie II 1536-1810, 1988 s. 244f (Lotte Dombernowsky) 